Chapman University

Chapman University Digital Commons

Food Science (MS) Theses

Dissertations and Theses

Spring 5-2020

\title{
Use of Molecular Methods to Authenticate Animal Species and Tissue in Bovine Liver Dietary Supplements
}

Olive Dahm

Chapman University, dahm@chapman.edu

Follow this and additional works at: https://digitalcommons.chapman.edu/food_science_theses

Part of the Food Studies Commons

\section{Recommended Citation}

Dahm, O. (2020). Use of molecular methods to authenticate animal species and tissue in bovine liver dietary supplements. Master's thesis, Chapman University. https://doi.org/10.36837/chapman.000140

This Thesis is brought to you for free and open access by the Dissertations and Theses at Chapman University Digital Commons. It has been accepted for inclusion in Food Science (MS) Theses by an authorized administrator of Chapman University Digital Commons. For more information, please contact laughtin@chapman.edu. 
Use of Molecular Methods to Authenticate Animal Species and Tissue in Bovine Liver

\title{
Dietary Supplements
}

\author{
A Thesis by \\ Olive Dahm \\ Chapman University \\ Orange, CA \\ Schmid College of Science and Technology \\ Submitted in partial fulfillment of the requirements for the degree of \\ Master of Science in Food Science
}

May 2020

Committee in Charge

Rosalee Hellberg

Debra K. W. Topham

John Miklavcic 
The thesis of Olive Dahm is approved.

Rosalee S. Hellberg

Rosalee Hellberg, Ph.D.

Associate Professor, Food Science Program

Schmid College of Science and Technology

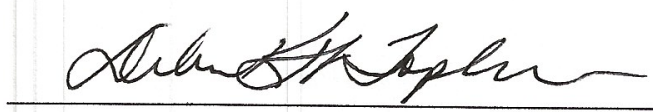

Debra K. W. Topham, M.S.

Part-Time Faculty, Food Science Program

Schmid College of Science and Technology

Natlem.

John Miklavcic, Ph.D.

Assistant Professor, Food Science Program

Schmid College of Science and Technology

April 2020 
Use of Molecular Methods to Authenticate Animal Species and Tissue in Bovine Liver Dietary

\section{Supplements}

Copyright $(\subset 2020$

by Olive Dahm 


\section{ACKNOWLEDGEMENTS}

I would like to thank my research advisor, Dr. Rosalee Hellberg, for her helpfulness and patience; Dr. Lilian Were, Dr. Criselda Toto Pascioles and my peers for their useful feedback; Georgia Sampson and AJ Silva for their help in the lab collecting data, and the committee members, Debra Topham and John Miklavcic, for their support and guidance.

Conflict of interest declaration: the author is employed at a dietary supplement manufacturing company. 


\section{ABSTRACT \\ Use of Molecular Methods to Authenticate Animal Species and Tissue in Bovine Liver Dietary Supplements}

by Olive Dahm

Dietary supplements containing bovine (subfamily Bovinae) liver are susceptible to fraud due to the lack of modern detection methods available for processed animal tissues and premium pricing for dietary supplements. Therefore, the objective of this research was to use molecular methods to authenticate dietary supplements claiming to contain "bovine liver" or "beef liver" through the verification of species and animal tissue. A total of 53 bovine/beef liver dietary supplements were purchased from online sources. The presence of liver was verified with reverse transcription and real-time PCR testing for microRNA-122 (miR-122), which is highly expressed in liver tissue. Multiplex real-time PCR targeting domestic cattle (Bos taurus), horse (Equus caballus), sheep (Ovis aries), and pork (Sus scrofa) was used to verify species. Samples that failed species identification with multiplex real-time PCR underwent DNA mini-barcoding. Overall, bovine species were detected in 48/53 liver supplements: 35 samples were confirmed as $B$. taurus with multiplex real-time PCR and an additional 13 samples were confirmed as $B$. taurus or Bos spp. with DNA mini-barcoding. One sample was positive for domestic cattle and sheep/lamb, both of which were declared on the label. One product was mislabeled due to the detection of undeclared pork in addition to beef. MiR-122 was detected in 51 out of 53 supplements, suggesting the presence of liver. Tissue-specific microRNAs can be reliable in identifying tissue and may be useful in detecting mislabeling in supplements. However, this was the first study to utilize microRNA for authentication of liver in dietary supplements and more research is needed to evaluate the specificity of these markers. 


\section{TABLE OF CONTENTS}

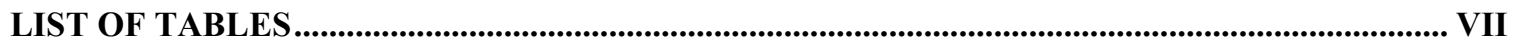

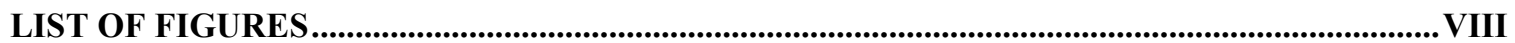

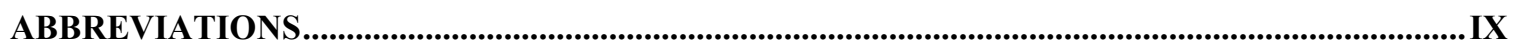

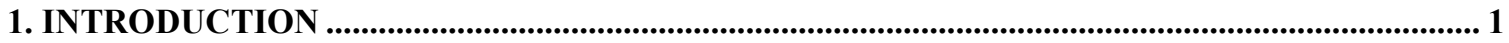

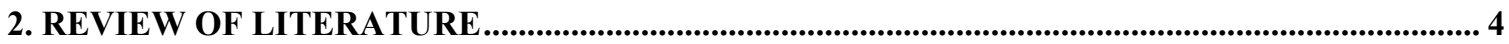

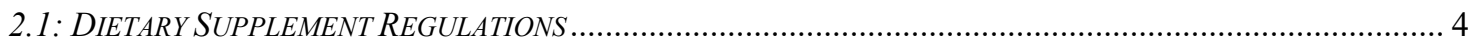

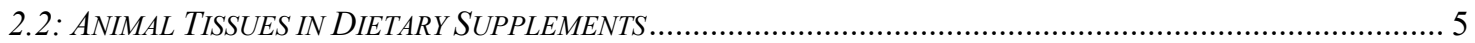

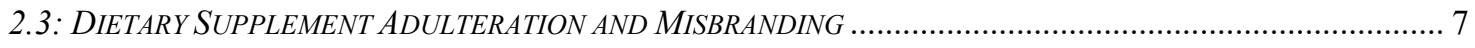

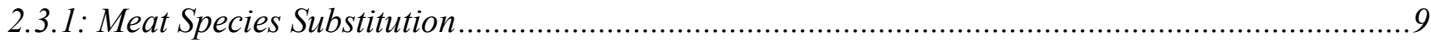

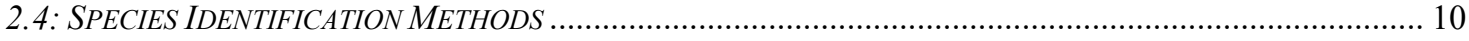

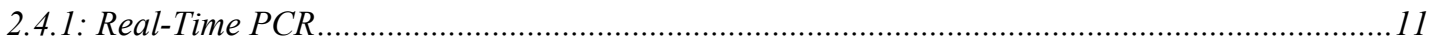

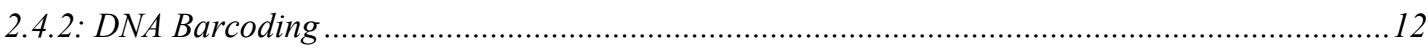

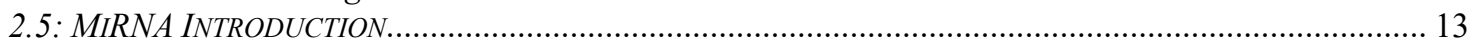

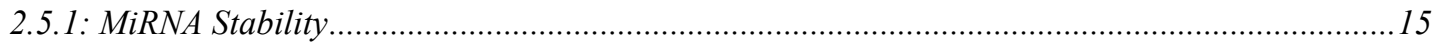

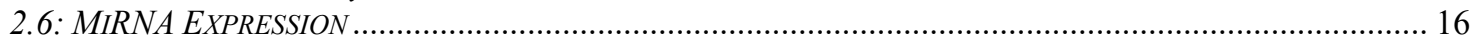

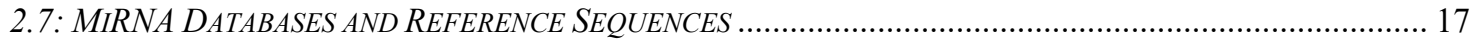

2.8: MIR-122

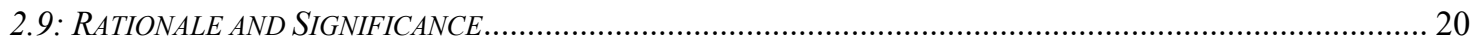

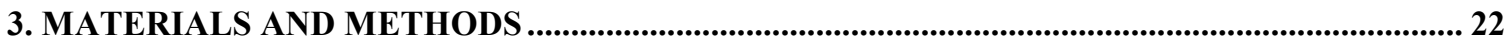

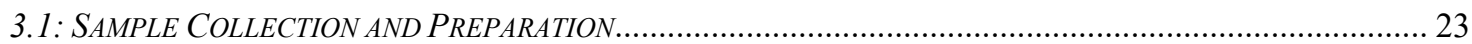

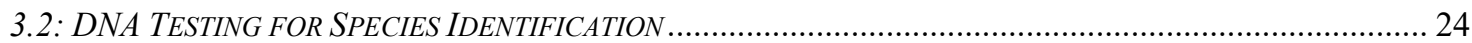

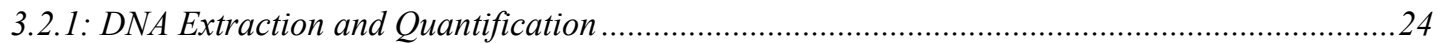

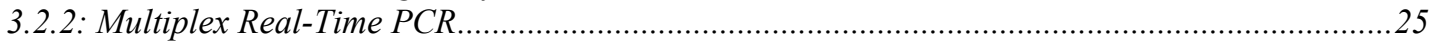

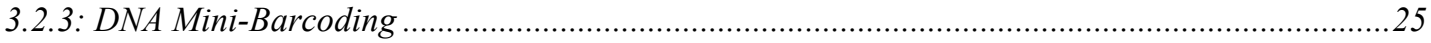

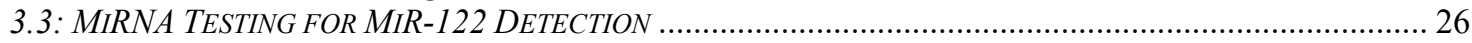

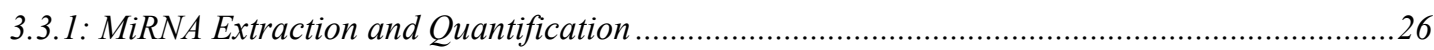

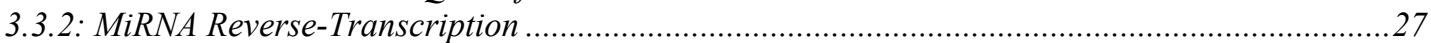

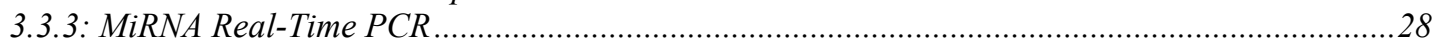

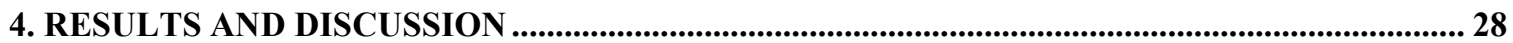

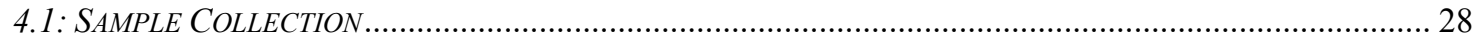

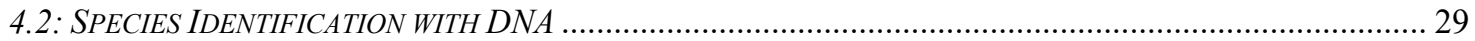

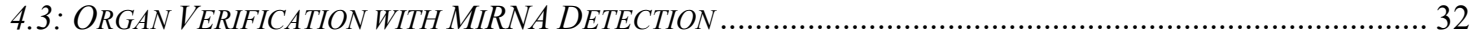

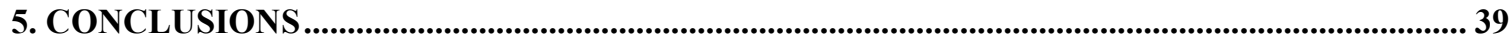

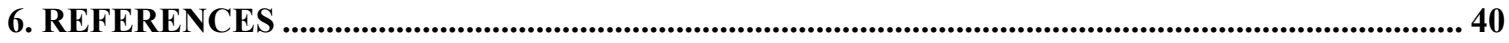




\section{LIST OF TABLES}

Table 1: Summary of benefits and limitations of genetic sample identification techniques. ....... 10

Table 2: Results of miRNA and DNA identifications for bovine liver supplements tested in this study. Samples were only subjected to DNA mini-barcoding if the real-time PCR assay failed to identify a species 


\section{LIST OF FIGURES}

Figure 1: Typical RNA extraction that isolates total RNA (Life Technologies Corporation, 2011)

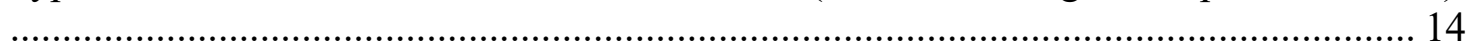

Figure 2: Overall procedure flow chart for dietary supplement analysis. White boxes indicate procedures, white circles: analysis method, and bullnose boxes: sample type. 


ABBREVIA
BOLD - Barcode of Life Database
COI - Cytochrome c Oxidase Subunit I
DNA - Deoxyribonucleic Acid
DSLD - Dietary Supplement Label Database
EMA - Economically Motivated Adulteration
EVmiRNA - Extracellular Vesicle microRNAs
FDA - U.S. Food and Drug Administration
GC\% - Guanine-Cytosine Content
GMP - Good Manufacturing Practices
IFT - Institute of Food Technologists
MiRNA - MicroRNA




\section{Introduction}

Dietary supplements are intended to supplement the diet with ingredients such as vitamins, minerals, amino acids, and herbs or botanicals (FDA, 2018b). However, factors such as a lack of proper Good Manufacturing Practices (GMPs), ingredient substitution or removal, and unscrupulous ingredient sourcing can lead to supplement adulteration (Brown, 2017). Under the Food Drug and Cosmetic (FD\&C) Act, dietary supplements are a category of food with labeling regulations and registry reporting system separate from food and drugs (FDA, 2018b). Intentional adulteration in dietary supplements typically involves the use of ingredients that are not listed on the label, such as undeclared drugs, to enhance claimed biologic or metabolic effectiveness; substitution of declared ingredients with cheaper alternatives; and use of unapproved non-dietary ingredients (NDIs) (Brown, 2017). Previous market surveys on the contents of dietary supplements have reported mislabeling rates of $25 \%$ for shark cartilage pills (Hellberg, Isaacs, \& Hernandez, 2019), 42\% for probiotic supplements (Morovic et al., 2016), and 58\% for botanicals (Newmaster et al., 2013). For example, studies have reported species substitution, such as alfalfa (Medicago sativa) substituted for elderberry (Sambucus nigra) and winter skate (Leucoraja ocellata) substituted for shark species (Hellberg et al., 2019; Newmaster et al., 2013), as well as probiotics that don't meet label claim or detection thresholds for strains listed on the label (Morovic et al., 2016 ).

Animal organs are sometimes used in dietary supplements because they contain vitamins, minerals, and amino acids essential to the human diet (Fayemi et al., 2018). Liver is the most common animal tissue used in dietary supplements, listed in over 140 known products according to the Dietary Supplement Label Database (DSLD) (NIH, 2019). Important nutrients found in the liver include vitamins A, E, B1, B2, B6, and B12; folate; biotin; niacin; and omega-3 fatty acids 
(Fayemi, Muchenge, et al., 2018). Beef is the main declared source of liver and other animal tissues in dietary supplements, followed by pork, sheep, and chicken (NIH, 2019). Liver as a dietary ingredient is susceptible to fraud because processing makes it visually appear similar to other dietary ingredients and there is no established method for tissue identification in processed dietary ingredient samples or finished dietary supplement products. Previous studies on meat mislabeling have reported species substitution and species mixtures in food products. For example, one study on ground meat products reported a mislabeling rate of $20 \%$ (Kane \& Hellberg, 2016) and another on organ meat foods reported 31\% mislabeling (Köppel et al., 2013). However, there is currently a lack of research on the mislabeling of dietary supplements containing liver.

Current molecular laboratory methods for detecting animal or plant ingredients in dietary supplements include real-time PCR and DNA barcoding. Real-time PCR is a targeted approach that uses species-specific primers to identify species in real-time (Köppel et al., 2013; Köppel et al., 2011). The combination of species-specific primers in a multiplex, real-time PCR assay allows for multiple species to be detected simultaneously. For example, Köppel et al. (2011) developed a multiplex real-time PCR assay with the commercial name AllHorse ${ }^{\mathrm{TM}}$ that simultaneously detects domestic cattle (Bos taurus) and several common substitute species, including pig (Sus scrofa), horse (Equus caballus), and sheep (Ovis aries). DNA barcoding uses universal primers that amplify a short, standardized region of DNA (Herbert, Cywinska, Ball, \& deWaard, 2003). For DNA barcoding of animal tissues, the most common target is a $\sim 655$ base pair (bp) region of the mitochondrial gene coding for cytochrome $c$ oxidase subunit I (COI). Because DNA degradation occurs during processing, test methods for animal species in processed products often target shorter regions of DNA called "mini-barcodes" (Hellberg et al., 
2019; Zahn et al., 2020; Wu et al., 2019). For example, one study reported increased success when using mini-barcoding compared to full-length DNA barcoding for the detection of species in shark cartilage dietary supplements (Hellberg et al., 2019). A novel DNA mini-barcode assay was developed specifically for the identification of animal species in processed foods; however, it has not yet been tested with dietary supplements (Wu et al., 2019).

Traditionally, histological and immunological methods are used to identify animal tissues (Sauer et al., 2017). However, identification is difficult with histological methods if the sample is processed and does not contain intact cells due to processing (Abdullah, 2008). Immunological methods can become costly and require specific assays (Sauer et al., 2017). RNA-based tests tend to be unreliable in aged or processed samples because RNA degrades faster than DNA (Sauer et al., 2017). However, many tissue-specific microRNAs (miRNAs) are relatively stable (Sauer et al., 2017). MiRNAs are 18-24 nucleotides in length and regulate gene expression by binding with a fully or partially complementary RNA-Induced Silencing Complex (RISC) that regulates messenger RNA (mRNA) expression. MiRNAs are more stable post-mortem compared to mRNA and RNA under normal conditions and in the presence of elevated temperature and RNases (Na \& Park, 2018). Forensics studies use miRNA detection for human fluid and tissue identification from residual samples (Sauer et al., 2017; Sauer et al., 2016). Although most miRNAs are conserved across species and in all tissues, miRNA markers have been identified in various animal tissues and species, resulting in species-specific miRNAs as well as tissuespecific miRNAs (Jin et al., 2009). Due to miRNA tissue specificity, there is potential to use miRNA to identify animal tissues in dietary supplements.

The objective of this study was to determine whether dietary supplements marketed as containing "bovine liver" or "beef liver" are accurately labeled with regards to the animal species 
and tissue type. The term "bovine" refers to an animal within the cattle group (subfamily Bovinae), while "beef "is meat from full-grown bovine/cattle (USDA, 2020b; Merriam-Webster, n.d.). A combination of DNA barcoding and real-time PCR identified species and miRNA testing verified the presence of liver.

\section{Review of Literature}

\section{1: Dietary Supplement Regulations}

Dietary supplements are regulated separately from food and drugs but are subject to 21 CFR 111 for current GMPs. The U.S. government first defined the standard of identity for dietary supplements in the Dietary Supplement Health and Education Act of 1994 as an amendment of the FD\&C Act. Dietary supplements contain ingredients, such as vitamins, minerals, botanicals, and amino acids, intended to supplement the human diet, or a "concentrate, metabolite, extract, constituent or combination" of any of the criteria listed above (FD\&C, 1938).

Dietary supplements are required to be compliant with 21 CFR $§ 101.36$ and must include a "Supplement Facts" panel (FDA, 2018b). Declared label ingredients must be listed on the Supplement Facts panel or ingredient list and must be present in the dietary supplement. Dietary supplement product labels and websites can contain nutrient content claims, structure/function claims and approved health claims. Nutrient claims indicate the levels of nutrients with established daily values in the product. For example, nutrient content claims can simply be claiming " $100 \%$ daily value" of a nutrient on the label. Structure/function claims state the role that vitamins/minerals have in preventing nutrient deficiency-related diseases or promoting regular health functions (FDA, 2018b). Structure/function claims may also state how an ingredient helps promote a healthy lifestyle, such as supporting a healthy weight or sleep. Despite being able to make these claims for dietary supplements, the label must include a 
required word-for-word disclaimer that the FDA has not evaluated the statement. FDA approved health claims may be used on dietary supplement product labels and websites; however, scientific evidence must support any new health claims, the FDA has to approve the claims, and the FDA may use enforcement discretion (FDA, 2018a). Drug labels can contain disease-related terminology such as: treats cardiovascular disease or reduces symptoms of hyperthyroidism. However, dietary supplements are narrowly limited on health claim usage because they are not intended to prevent, cure, or mitigate diseases or their symptoms (FD\&C, 1938; FDA, 2018b).

This research is important for current GMP (cGMP) compliance for dietary supplements. Manufacturers must establish product ingredient specifications for identity, purity, strength, and composition (21 C.F.R. $\S 111.70,2020)$. In addition, manufacturers must have contamination limits to prevent adulteration and preserve quality (21 C.F.R. $\S 111.70,2020)$. These standards can be verified using molecular methods.

\section{2: Animal Tissues in Dietary Supplements}

Dietary supplements sometimes include organ meats because they contain vitamins, minerals, and amino acids essential to the human diet (Fayemi, Muchenge, Yetim, \& Ahhmed, 2018). According to the Dietary Supplement Label Database, the top 10 animal tissues used in dietary supplements are, in descending order: liver, thymus, spleen, cartilage, pancreas, pituitary, orchic, kidney, antler velvet, and parotid (NIH, 2019). The most common source of animal tissues used in dietary supplements is beef $(\mathrm{NIH}, 2019)$. Important nutrients found in the liver include vitamins A, E, B1, B2, B6, and B12; folate; biotin; niacin; and omega-3 fatty acids (Fayemi, Muchenge, et al., 2018). Liver may also be perceived as "detoxifying" due to early studies claiming that supplementing the diet with liver can counteract the effects of toxic drug doses or increase swimming endurance (Ershoff, 1951; 1952). Another group of researchers 
suggested that nutrient-rich organ meats, such as liver, heart, kidney and brain, would be a good source of nutrients for malnourished populations (Fayemi et al., 2018). Despite the widespread availability and popularity of these supplements, no studies have been published evaluating whether dietary supplements actually contain the tissue declared on the label.

Although animal organs contain essential nutrients for human health, they can also contain undesirable elements. For example, Hashemi (2018) showed that lead and mercury concentrations in bovine liver were over the minimal risk level for $15.3 \%$ and $8.3 \%$ of samples, respectively, and heavy metal concentrations in meat and organs seemed to fluctuate greatly between countries of origin. The FDA issued an import alert in 2018 concerning any dietary supplements contaminated with heavy metals (FDA, 2018c). Although there have been no recalls or import alerts by the FDA for animal livers, in 2014, they issued a warning letter to a company selling bovine meat with drug concentrations greater than the allowed amount (FDA, 2014).

Gochfeld and Burger (1987) studied the heavy metals present in the organs of three avian species. They discovered that zinc and copper were the most abundant in all three duck species and both sexes of duck tested. Cadmium, cobalt, and mercury were consistently present in trace amounts. They also found that there was variation in the levels of metals for species and sex for black ducks (Anas platyrhynthos) and scaup (Aythya marila). Although zinc and copper are considered essential minerals, they can be toxic depending on the dose. These results emphasize the importance of the careful selection of species and their organs for human consumption.

The presence of prions in animal tissues can cause disease in humans (Belay, 1999; Belay $\&$ Schonberger, 2005). The prevalence of prion disease in sheep and cattle has not decreased in the UK, US, and Canada, and recommended efforts should be followed to avoid consumption of contaminated specimens (Boelaert et al., 2016). Prion contaminated meat is typically removed 
from the food supply, but it is also recommended that consumers avoid eating high-risk animal parts, such as the spleen and brain. However, there are multiple dietary supplements available on the U.S. market that contain spleen and brain tissue (Huyben et al., 2018; NIH, 2019). There is also the risk of spinal cord and central nervous system cross-contamination during processing (Gangidi \& Proctor, 2009). Currently, there is no research on whether dietary supplements containing animal tissues, such as the brain or spleen, also contain prions.

\section{3: Dietary Supplement Adulteration and Misbranding}

The FD\&C Act of 1938 defines misbranding as a mislabeled, counterfeit, or imitation product (FD\&C, 1938). Fraud, on the other hand, is defined as "the act of defrauding buyers of food or ingredients for economic gain" (Johnson, 2014). The FDA uses the term Economically Motivated Adulteration (EMA) to describe the adulteration of a product for economic benefit (Johnson, 2014).

There are many types of EMA, including dilution with water or a filler, ingredient replacement with a substitute, and addition of ingredients to mask inferior quality or increase potencies, such as adding caffeine to dietary supplements containing inherent caffeine such as kola nut (Cola acuminata) or tea (Camellia sinensis) (FDA, 2017; Newmaster et al., 2013). Mislabeling includes false declarations of origin, undeclared ingredients, and noncompliance to label regulations. For example, some dietary supplements contain illegal, unlisted drugs to enhance dietary supplement effectiveness for structure/function claims (Benatrehina et al., 2018). Sometimes, cheaper botanical substitutions or fillers replace expensive herbal ingredients without a label change, such as replacement of Echinacea purpurea with Parthenium hysterophorus, Ginkgo biloba with Juglans nigra or Oryza sativa, and Rubus idaeus with Medicago sativa (Newmaster et al., 2013). One study found that $21 \%$ of 44 botanical dietary 
supplements tested contained fillers such as rice (Oryza sativa) and soybean (Glycine max) (Newmaster et al., 2013). However, it is important to note that dietary supplements and other food products are allowed to contain incidental additives which are exempt from label declarations (21 C.F.R. $\S 101.100,2020$ ). Incidental additives are defined in 21 C.F.R. $\S 101.100$ (2020) as substances present at insignificant levels that don't have a functional or technical effect in the food, processing aids or non-food additive substances that enter the food from contact with equipment or packaging.

Dietary supplements must meet label claims at the end of shelf life despite any ingredient sensitivity to degradation (FDA, 2018b). Morovic et al. (2016) found that $42 \%$ of 52 probiotic dietary supplements tested contained undeclared microorganisms or did not contain all of the probiotics listed on the label. Although probiotics and other ingredients lose viability and degrade over time, dietary supplement ingredients are required to meet $100 \%$ or more of label claimed quantities throughout the entirety of shelf life, otherwise the product is considered misbranded by the FDA (21 C.F.R. $\S 101.36,2020)$. Although some studies have quantified dietary ingredients, this thesis research did not quantify the ingredients in bovine liver dietary supplements.

Some researchers have conducted studies evaluating species fraud in dietary supplements. A study by Hellberg et al. (2019) identified shark species in shark cartilage dietary supplements and found species mislabeling, although they did not conduct cartilage presence verification. Some of the species found in these shark supplements were considered threatened, vulnerable, or endangered (Hellberg et al., 2019). This study also identified wild rice (Oryza rufipogon), a common filler. Wallace et al. (2012) used DNA barcoding to identify animal and plant species in natural health products. These researchers also found similar trends where 
ingredients, such as green tea, were replaced with fillers like rice. Ingredients, such as Korean ginseng, were also replaced with cheaper or related species not listed on the label, such as American ginseng. Wallace et al. (2012) also tested shark supplements and found similar mislabeling results compared to Hellberg et al. (2019).

Although studies have not examined the substitution of animal tissues, there is a strong economic incentive to substitute one animal species for another. For example, the average retail price of beef liver sold at five different online sources in the United States in April 2020 was $\$ 6.67 / \mathrm{lb}$, which is more expensive than chicken liver sold online with an average price of $\$ 2.92 / 1 b$. This price difference can motivate companies to substitute chicken for beef to make a profit. Most offal or organ meats are lower in price than muscle meat, however (Fayemi et al., 2018).

\subsection{1: Meat Species Substitution}

Dietary supplement manufacturers rely on suppliers for their meat ingredients. Despite the health consequences of adulteration, market surveys have found that mislabeling is common among food. Researchers reported that $20.8 \%$ of 48 raw ground meat samples purchased from online specialty stores, butchers, and retail markets were mislabeled in one study (Kane \& Hellberg, 2016). Other researchers found a 15.9\% mislabeling rate of 806 raw meat products in Florida retail markets (Hsieh et al., 1995). Another study found that $31.0 \%$ of 29 animal organ foods- Mousse, Rillettes, and Foie gras- contained undeclared species or different amounts of species compared to the label claim (Köppel et al., 2013).

Some individuals have allergies or religious affiliations that prevent them from consuming certain meats. Religious restrictions include halal and kosher. For halal, pork is not allowed, and beef is allowed with halal processing conditions. For kosher, pork and non-kosher 
gelatin for capsules is not allowed. Fraud of kosher and halal meats has been reported in the food supply (Danezis et al., 2016). Allergies can severely endanger the life of an immunocompromised or allergen-sensitive person when they ingest an inappropriately labeled or contaminated food. There have been reports of allergic reactions after the ingestion of red meat and poultry (Hemmer et al., 2016; Wong \& Sebaratnam, 2018). Horse meat is taboo, illegal, or against religious practices for human consumption in the United States and many other countries (California Attorney General, 2015). However, during the European horsemeat scandal in 2013, the Food Safety Authority of Ireland (FSAI) found multiple foods containing undeclared horsemeat (FSAI, 2013).

\section{4: Species Identification Methods}

Table 1: Summary of benefits and limitations of genetic sample identification techniques.

\begin{tabular}{|c|c|c|c|c|}
\hline Method & Applications & Benefits & Limits & Source \\
\hline $\begin{array}{l}\text { Next- } \\
\text { Generation } \\
\text { Sequencing }\end{array}$ & Species ID & $\begin{array}{l}\text { mixed samples } \\
\text { allowed, } \\
\text { universal primers }\end{array}$ & $\begin{array}{l}\text { Intact DNA } \\
\text { required, time- } \\
\text { consuming, } \\
\text { expensive, large } \\
\text { amount of data }\end{array}$ & $\begin{array}{l}\text { (Schwarze et } \\
\text { al., 2018) }\end{array}$ \\
\hline $\begin{array}{l}\text { DNA } \\
\text { Barcoding }\end{array}$ & Species ID & $\begin{array}{l}\text { Database } \\
\text { references, } \\
\text { standard } \\
\text { procedures, } \\
\text { universal primers }\end{array}$ & $\begin{array}{l}\text { Only tests } \\
\text { maternal DNA, } \\
\text { pure sample } \\
\text { needed }\end{array}$ & $\begin{array}{l}\text { (Hellberg et } \\
\text { al., 2019; } \\
\text { Weigt et al., } \\
\text { 2012) }\end{array}$ \\
\hline $\begin{array}{l}\text { Targeted } \\
\text { PCR }\end{array}$ & Species ID & $\begin{array}{l}\text { mixed samples } \\
\text { allowed, } \\
\text { standard } \\
\text { procedures }\end{array}$ & $\begin{array}{l}\text { Primer } \\
\text { interactions, } \\
\text { targeted approach }\end{array}$ & $\begin{array}{l}\text { (Köppel et al., } \\
\text { 2013) }\end{array}$ \\
\hline $\begin{array}{l}\text { MiRNA } \\
\text { Detection }\end{array}$ & $\begin{array}{l}\text { Forensics, } \\
\text { Tissue ID, } \\
\text { Disease ID }\end{array}$ & $\begin{array}{l}\text { Sensitive, stable, } \\
\text { mixed samples } \\
\text { allowed }\end{array}$ & $\begin{array}{l}\text { Need tissue- or } \\
\text { species-specific } \\
\text { miRNA and } \\
\text { amplification, no } \\
\text { complete database }\end{array}$ & $\begin{array}{l}\text { (Sauer et al., } \\
2017 \text { ) }\end{array}$ \\
\hline
\end{tabular}


Common methods used for species identification include DNA-based techniques, such as DNA barcoding and PCR. However, none of these methods can detect the presence of specific tissues in a sample. MiRNAs are a promising biomarker for determining the organs present in a sample. Table 1 contains a summary of the pros and cons of each detection method is in.

\subsection{1: Real-Time PCR}

First proposed in 1985, Polymerase Chain Reaction (PCR) is a process of replicating DNA (Mullis \& Faloona, 1987; Saiki et al., 1988). First, denaturation of DNA separates the double helix into its two strands. The primers anneal to their complementary DNA portions and DNA polymerase synthesizes new daughter strands attached to the parent strands (Saiki et al., 1988). This process cycles repeatedly until the achievement of the desired replication amount. Uses of PCR include the detection of species' DNA and DNA cloning (Saiki et al., 1988). PCR is crucial for analyzing samples with degraded or small amounts of DNA.

The processing carried out during the production of dietary supplements can hinder DNA extraction, which leads to difficulties in obtaining data (Mano et al., 2017). Shear forces, elevated temperatures, enzymes, and extreme $\mathrm{pH}$ conditions damage DNA. Real-time PCR, where the sample's DNA is amplified and detected in real-time using fluorescence, is able to detect the residual DNA. Additionally, real-time PCR can be used for the quantification of DNA in the sample. Fragmentation can lead to the underestimation of DNA present since the primers may not be able to bind to their target sequence. Therefore, it is important to have internal references and controls while conducting real-time PCR to avoid false negatives and false positives.

Multiplex real-time PCR is advantageous over singleplex real-time PCR because it detects multiple species in an ingredient mixture (Dalsecco et al., 2018; Kane \& Hellberg, 2016; 
Köppel et al., 2013; Köppel et al., 2011; Mohamad et al., 2018). For example, one study reported the ability of multiplex real-time PCR to verify the presence of chicken and pork in poultry and meat samples, respectively (Wang et al., 2018). Many multiplex real-time PCR assays have been developed for the simultaneous detection of multiple species in a sample. For instance, Köppel et al. $(2013 ; 2011)$ created a primer cocktail for the detection of cattle, pork, horse, and sheep (AllHorse ${ }^{\mathrm{TM}}$ ), as well as a primer cocktail for the detection of pork, chicken, turkey, and goose (AllPâté ${ }^{\mathrm{TM}}$ ). Köppel et al. (2011) found that the AllHorse assay could detect the species in a mixed sample with total species DNA concentrations as low as $0.32 \mathrm{ng}$. The only cross-reactivity $(0.1 \%)$ they found was horse with donkey (Equus asinus) and mule (mulus). The AllPâté assay had some cross-reactivity $(0.1 \%)$ with closely-related avian species and detected species present at DNA concentrations as low as $0.4 \mathrm{ng}$ for turkey and $0.2 \mathrm{ng}$ for the other targets (Köppel et al., 2013).

\subsection{2: DNA Barcoding}

DNA barcoding uses a standardized region of the genome as a species indicator in a pure sample (Ivanova et al., 2012; Kress \& Erickson, 2008). The standard region used for the identification of animal species with DNA barcoding is a $\sim 650 \mathrm{bp}$ section of the mitochondrial gene coding for COI (Folmer et al., 1994; Herbert et al., 2003). The circular mitochondrial genome was first imaged in 1979 and is well conserved in eukaryotes yet different enough to distinguish between species (Hsu \& Coca-Prados, 1979). A universal primer set binds to the DNA barcode and the resulting sequence is compared to known species' sequences in a database, such as GenBank or BOLD. This method has been used for the identification of a range of animal species in food products, such as meat and poultry samples (Ballin, 2010; Dalsecco et al., 2018; Hellberg et al., 2017; Kane \& Hellberg, 2016; Mano et al., 2017). 
While DNA barcoding is an important method for the identification of animal species in foods, it does have some limitations. For example, hybrid species cannot be identified through DNA barcoding because the mitochondrial DNA is inherited maternally. Additionally, samples containing multiple species often cannot be identified using DNA barcoding, as the simultaneous amplification of DNA from these species causes a mixed sequencing signal (Hellberg \& Morrissey, 2011; Kane \& Hellberg, 2016). In addition, traditional full-length DNA barcoding using the $650 \mathrm{bp}$ region is not feasible with heavily processed or degraded samples since there is a risk that the DNA will be fragmented or damaged (Mano et al., 2017). Some researchers have used mini-barcoding instead, which requires shorter sequences $(<250 \mathrm{bp})$, to identify species in processed samples (Hellberg et al., 2017; Hellberg et al., 2019; Wallace et al., 2012). For example, mini-barcoding with primers developed by Fields et al. (2015) successfully identified shark species in shark cartilage dietary supplements that failed identification with full-length barcoding (Hellberg et al., 2019). However, in a study on meat species identification, Hellberg et al. (2017) found that the universal mini-barcode primers developed by Meusnier et al. (2008) were not reliable in identifying beef, chicken, and bison in meat and poultry samples. Wu et al. (2019) tested a different set of mini-barcoding primers on a variety of mammalian, poultry, and fish species, as well as processed food products, and found that the species could reliably be determined. Sultana et al. (2018) applied mini-barcoding to processed Malaysian fish products and found that the barcode marker used was reliable at identifying all 33 fish species tested.

\section{5: MiRNA Introduction}

MiRNAs are small, non-coding RNAs that can influence tissue differentiation, gene regulation, disease susceptibility, and growth maturation (Courts \& Madea, 2010). The discovery of miRNAs occurred while researchers studied the lin-4 gene in roundworms (Caenorhabditis 
elegans), where instead of coding for a protein, this gene encoded a miRNA that targeted the lin14 messenger RNA (mRNA) (Lee et al., 1993).

MiRNAs are typically 18-25 nucleotides long, which makes detection methods difficult since most methods isolate larger RNA, shown in Figure 1 (Mraz et al., 2009). RNA isolation methods can lose these small RNAs due to their size or, compared to large RNA molecules, not contribute significantly to test results. They could also have been considered fragments and contaminants of larger nucleic acids during quantification, and therefore ignored. Total RNA extraction does not always extract miRNAs, and additional steps are sometimes needed to isolate and detect miRNAs (Ma et al., 2018).

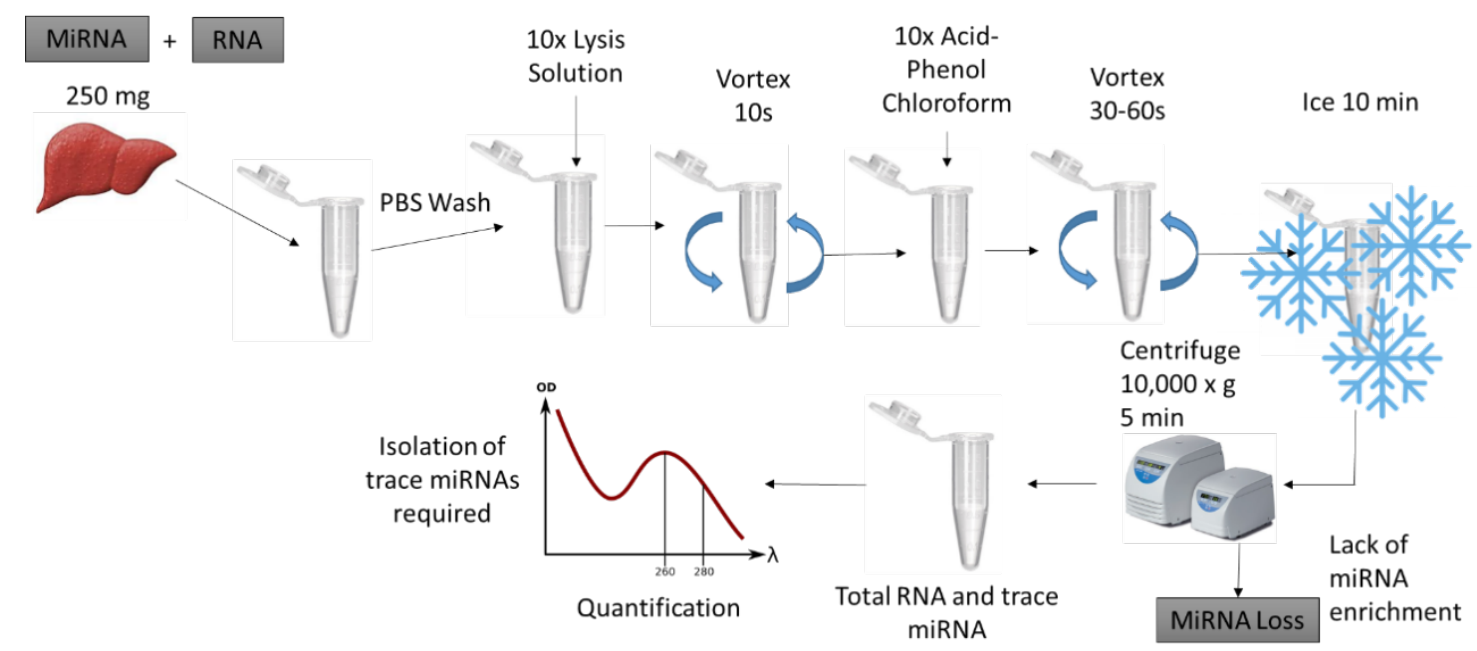

Figure 1: Typical RNA extraction that isolates total RNA (Life Technologies Corporation, 2011)

The first step in miRNA formation through the typical canonical processing pathway is the transcription of primary miRNAs (pri-miRNA) from non-protein coding DNA gene introns using RNA polymerase II in the nucleus (Courts \& Madea, 2010; Gustafson et al., 2016; Wang et al., 2013). The enzyme Drosha, along with the protein-coding gene DGCR8, separate the primiRNAs into 60-100 nt precursor miRNAs (pre-miRNA). Exportin-5 proteins and the G-protein Ran export the pre-miRNAs into the cytoplasm where the Dicer enzyme cleaves the pre- 
miRNAs into miRNA duplexes, a double-stranded miRNA consisting of a mature strand and a degrading strand. Each strand is assigned $-5 p$ or $-3 p$ suffixes, depending on their position (Gustafson et al., 2016). Upon the formation of the mature miRNA, the strands separate, and the miRNA guide strand merges with a fully or partially complementary RNA-induced silencing complex (RISC), which moves to the nucleus to influence mRNA regulation. The degraded strand typically breaks down but sometimes also has RISC targets (Wang et al., 2013). The miRNA's 8-base seed region determines the target RISC and is highly conserved between 15 evaluated animal species, including human, horse, sheep, pork, fish, fruit fly (Drosophila melanogaster), and cattle (Zorc et al., 2015).

\subsection{1: MiRNA Stability}

MiRNAs are used in human (Homo sapiens) forensics because they are stable enough to survive harsh environmental conditions, such as temperature and $\mathrm{pH}$, for prolonged periods and be detectable at low levels (Courts \& Madea, 2010). Sauer et al. (2016) compared miRNA expression profiles from human bodily fluid samples with varying age and found that miRNAs were stable and detected even after 35 years (Sauer et al., 2016). Since miRNAs can be tissuespecific, detection can determine whether a victim has fatal wounds with just a residue on a weapon (Sauer et al., 2017).

Studies in humans have shown that mono-uridylation of pre-miRNAs promotes miRNA biogenesis and mono-adenylation promotes miRNA stability (Jopling, 2012; Song et al., 2015). The miRNA's nucleotide sequence also influences its stability (Bail et al., 2010). Kakimoto et al. (2016) have shown that a miRNA's half-life depends on the guanine-cytosine content (GC\%), with GC\% above 40 yielding the greatest stability. Bail et al. (2010) found 5 out of 99 miRNAs had half-lives of $8 \mathrm{~h}$ or less. However, $95 \%$ of miRNAs studied did not decrease within 8 -hours 
and many of these miRNAs are successful with verifying human tissues in aged forensic samples (Sauer et al., 2017). Therefore, it is important to select stable miRNAs for tissue identification that will still be present after processing. Bail et al. (2010) also suggested that miRNA stability is influenced by the cell type, as well as whether the miRNA was intracellular or extracellular. Fang et al. (2019) found that miRNAs in the blood are stable under ambient conditions. Factors that affect miRNA degradation in human blood include multiple freeze-thaw cycles and high concentrations of sodium hypochlorite (Fang et al., 2019). Liver samples may contain trace amounts of blood that could affect miRNA detection. It is also possible that liver miRNAs are susceptible to the same degradation conditions as blood miRNAs.

\section{6: MiRNA Expression}

MiRNAs can be expressed differently in tissues, bodily fluids, and species. Therefore, they are a good indicator of tissue type and can identify tissues in mixtures where multiple species and tissues are blended. Tissues exhibit miRNA signatures that can help to identify them in a sample by detecting a miRNA unique to the tissue or a combination of miRNAs present in

the tissue. For example, researchers found that miR-122 is highly expressed in the liver; miR-483 in connective tissue; miR-1 in heart; and miR-146a, -200a and -b in kidneys (Gustafson et al., 2016; Jin et al., 2009; Lagos-Quintana et al., 2002). MiRNAs can participate in cell-to-cell signaling and many are found in bodily fluids (Hollis \& Starkey, 2018). They are protected in these fluids by RNA-binding proteins or extracellular vesicles (Hollis \& Starkey, 2018). There have been four bovine-specific miRNAs discovered by Jin et al. (2009). However, most miRNAs are conserved across species and it is unknown if these miRNAs are conserved in other species not yet analyzed. Hanif et al. (2018) found that there were variations in gene copy numbers of miRNAs between domestic cattle and zebu (Bos indicus) and that miRNAs can have mutation 
differences, most commonly substitution, between species. For example, miRNA tissue expression in porcine liver includes miR-103 and let-7a (Bae et al., 2018).

Some miRNAs are involved in tissue differentiation and development during growth phases, such as mir-1 and mir-35 in the development of heart muscle (Hicks et al., 2009; Kwon et al., 2005; Renalier et al., 2011). MiRNAs that are found abundantly in a tissue may affect the development of that tissue (Alvarez-Saavedra \& Horvitz, 2010; Renalier et al., 2011). For example, mir-7 is highly expressed in eye tissue in Drosophila and influences eye development (Li \& Carthew, 2005). Since miRNAs are non-coding, they often do not have any phenotypic effect (Renalier et al., 2011). However, knocking out or modifying an entire miRNA family has been shown to affect phenotypic development and function (Chen et al., 2014). Interestingly, some miRNAs have distinct expression patterns when tissue injury is present (Morrison, 2018; Permenter et al., 2019). MiRNAs are being studied for their use to identify and treat diseases. They contribute many functionalities, such as immunity, heat tolerance, pregnancy, and cancer (Hanif et al., 2018; Ioannidis \& Donadeu, 2016). MiRNAs help suppress genes and play roles in disease susceptibility and resistance (Wang et al., 2013).

\section{7: MiRNA Databases and Reference Sequences}

MiRNAs are still being discovered and understood with the help of several databases for miRNAs, including miRBase, EVmiRNA, Dietary miRNA Database (DMD), miRGen, and miRNEST. Jin et al. (2009) created a library of miRNAs found from select bovine tissues, including liver, and compared their results to known species-specific miRNAs. Andreote et al. (2014) created a library of miRNAs they found in domesticated chicken (Gallus gallus) skeletal muscle. Chen et al. (2017) created a library for miRNAs found in Laiwu and Yorkshire pigs (Sus scrofa). MiRNAs in zebu cattle (Bos indicus) and from databases showed that 736 of the 808 
domestic cattle (B. taurus) miRNAs were conserved in the zebu (Hanif et al., 2018). A Dorset sheep (Ovis aries) miRNA library was created by researchers, with information about miRNA conservation between $B$. taurus and $O$. aries species (Laganà et al., 2015). There is also a database for food-borne miRNAs (Chiang et al., 2015).

\section{8: MiR-122}

MiR-122 is highly expressed in the liver of vertebrates (Chang et al., 2004; Jopling, 2012). Researchers have found that approximately $50-72 \%$ of miRNAs per liver cell in mice (Mus musculus) and humans are miR-122 (Jopling, 2012; Lagos-Quintana et al., 2002; Liang et al., 2007). Heneghan et al. (2011) confirmed that miR-122 is expressed in blood, although it not as highly expressed as in the liver. The alpha-helix coiled-coil rod homologue (HCR) gene and a noncoding gene on chromosome 18 encode for miR-122 through the circadian process in various mammals (Chang et al., 2004; Jopling, 2012). Researchers found that 3' adenylation causes greater miR-122 isoform stability (Jopling, 2012), and the half-life of miR-122 is estimated to be over 24 h (Gatfield et al., 2009).

Factors that influence miRNA expression include disease, species, age, time of year, and tissue type. Casas et al. (2016) reported that miR-122 in domestic cattle is upregulated in the spring but downregulated in the summer. Liver of older animals, fetal muscle tissue, and oocytes upregulate bta-miR-122 (Casas et al., 2016; Z. Wang et al., 2013). Serum miR-122 levels increase post-mortem, especially when liver damage is present (Clarke et al., 2017). MiR-122 expression levels can be different between closely related species, such as yak (Bos grunniens) and domestic cattle (Guan et al., 2017). MiR-122 levels in cynomolgus monkey (Macaca fascicularis) plasma are high enough that detection doesn't require pre-amplification (Iguchi et al., 2018). 
Gustafson et al. (2016) suggested that sample contamination is likely if miR-122 is detected when human liver is not present. However, since miR-122 is a circulating miRNA present in serum, there can be positive results depending on slaughter conditions, presence of blood, and physical condition of the sample before slaughter (Heneghan et al., 2011). High circulating levels of miR-122 is associated with the presence of tumors and hepatic injury (Wang et al., 2016). Research supports that miR-122 is highly expressed in the liver of most species, including cattle (Gu et al., 2007; Sun et al., 2014). Studies have been conflicting on whether miR-122 is found in adipose tissue, although most studies only analyze the miRNAs in a few select tissues. Lagos-Quintana et al. (2002) found that miR-122 was liver-specific when analyzing the following mouse tissues: heart, liver, kidney, lung, colon, midbrain, cortex, cerebellum, small intestine, and spleen. Liang et al. (2007) tested over 40 healthy human tissues, including adipose and liver. While the liver contained high expression of miR-122, they also found 34 and 19 copies of miR-122 in brain and thymus tissues, respectively. Researchers such as Liao et al. (2018) did not detect any miR-122 expression in the brain, however. Multiple studies did not detect miR-122 in adipose tissue (Gu et al., 2007; Liang et al., 2007). Zhao et al. (2009) stated that adipose tissue expresses miR-122 at levels 200 times less than the liver. Some studies even suggest that miR-122 expression is differentiated between different types of adipose tissue. Heneghan et al. (2011) discovered that miR-122 is expressed more in obese omental and non-obese subcutaneous human adipose tissue. Liao et al. (2018) studied longissimus dorsi intramuscular adipose tissue in Xinjiang brown cattle breeds. They found that miR-122 affected adipocyte differentiation in both humans and cattle (Liao et al., 2018). Liao et al. (2018) also showed that miR-122 expression distinguishes between subcutaneous and visceral human adipose tissues. In contrast, many studies involving miRNA expression in adipose tissue-related 
research do not mention miR-122, possibly because it was not tested for or not detected (Romao et al., 2012, 2014).

\section{9: Rationale and Significance}

Despite FDA enforcement of dietary supplement regulations, adulteration is still occurring. Adulteration can infringe on religious practices and be harmful to human health due to possible exposure to heavy metals, prions, and other contaminants. There is currently no accepted method for detecting the authenticity of specific animal tissues declared to be in dietary supplements. While miRNAs have a high potential for this application, they have not been tested with dietary supplements. DNA-based methods, such as real-time PCR and DNA barcoding, are successful for species identification in food products and could be used in a complementary manner with miRNAs to authenticate both species and tissues in dietary supplements. However, the combined use of these methodologies for this purpose has not been reported.

The objective of this study was to determine whether dietary supplements marketed as containing "bovine liver" or "beef liver" were accurately labeled with regards to species and tissue. The research utilized miRNA detection to verify the presence of vertebrate liver tissue and a combination of DNA mini-barcoding and real-time PCR to identify species. The multiplex, real-time PCR assay targeted the following species: cattle (Bos taurus), pork (Sus scrofa), horse (Equus caballus), and sheep (Ovis aries) (Köppel et al., 2011). The hypothesis was that by using highly expressed miRNAs, real-time PCR, and DNA mini-barcoding, sample species and tissues would be verified in bovine/beef liver dietary supplements (Brown, 2017; Hellberg et al., 2019; Newmaster et al., 2013; Sauer et al., 2017).

The following aims addressed the overall goal of determining the authenticity of species and tissue type in dietary supplements containing animal tissues. 
- Aim 1 tested for the presence of miR-122. MiR-122 has been isolated from liver, adipose, and serum and was the marker used for target tissue detection (Jin et al., 2009). Since miRNAs are relatively stable, they were expected to remain intact in dietary supplements and be readily detected (Jin et al., 2009; Sauer et al., 2017). Liver would only be identified if a positive result if the miRNA was found.

- $\quad$ Aim 2 used multiplex real-time PCR to identify horse, cattle, sheep, and pork in samples. This assay detected trace amounts of contaminant species present in a mixture and identified multiple species simultaneously. The expectation was the replacement of beef with a less expensive species, such as chicken (Hellberg et al., 2017; USDA, 2020a).

- $\quad$ Aim 3 used DNA mini-barcoding for species detection in samples that test negative for all species targeted with real-time PCR (i.e., horse, cattle, sheep, and pork). COI gene markers and online reference databases, BOLD and GenBank, identified the species (Kane \& Hellberg, 2016).

This was the first study to detect both miRNAs and DNA in dietary supplements containing animal tissues. The results of this study provided a baseline for the current adulteration of dietary supplements containing liver tissue in the United States market. The research will benefit government agencies, consumers, and the research community by authenticating the animal tissues declared in dietary supplements. 


\section{Materials and Methods}

Figure 2 is an experimental overview of the methodology used in this study. Subsequent sections describe further details.

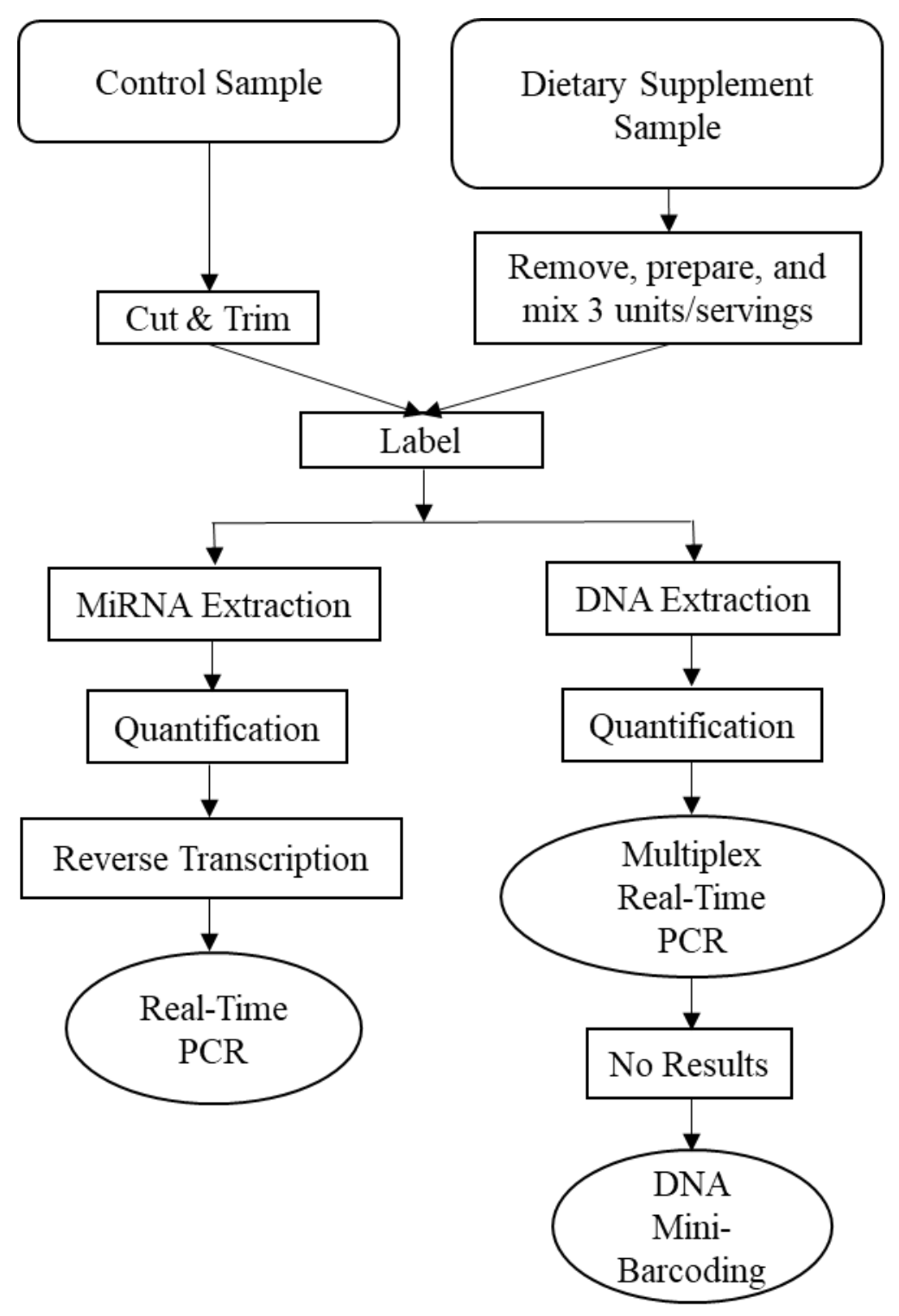

Figure 2: Overall procedure flow chart for dietary supplement analysis. White boxes indicate procedures, white circles: analysis method, and bullnose boxes: sample type. 


\section{1: Sample Collection and Preparation}

Dietary supplements claiming to contain "bovine liver" or "beef" liver $(\mathrm{n}=53)$ were purchased from five online sources available to USA-based consumers. The 53 supplements purchased were in the form of hard gelatin or vegetarian capsules $(n=40)$, tablets $(n=7)$, soft gelatin capsules $(n=1)$, and powders $(n=5)$. Four of the supplements in powder form were marketed specifically for pets, while the remaining supplements appeared to be intended for human consumption. Each sample was assigned a sequential number and all information on the label was recorded. Dietary supplement samples were prepared for molecular testing following procedures described in Hellberg et al. (2019). Three solid-dosage units were removed from each bottle, or three servings for powders, with sterile forceps for a single composite sample. Capsule casings were removed and tablets were crushed using a mortar and pestle. The composite samples were stored in sterile $50-\mathrm{mL}^{\text {Corning }}{ }^{\mathrm{TM}}$ polypropylene conical centrifuge falcon tubes (Corning, NY) at room temperature.

Positive and negative control samples were obtained for use with miRNA and DNA testing. Horse DNA was purchased from Zyagen (San Diego, CA) and raw beef liver, beef muscle, pork muscle, and lamb muscle cuts were purchased from local grocery stores in Orange County, California. The beef liver was used as a positive control sample for miR-122 in miRNA testing and the beef muscle was used as a negative control for miR-122. The horse DNA and raw muscle cuts were used as species positive controls for DNA testing. Control sample muscle cuts were verified for the correct species using multiplex real-time PCR, as described below. The raw liver and muscle cuts were stored in re-sealable zipper storage bags at $-80{ }^{\circ} \mathrm{C}$ following collection and the horse DNA was stored at $-20^{\circ} \mathrm{C}$. Prior to DNA extraction, the raw muscle cuts 
were thawed at $4{ }^{\circ} \mathrm{C}$ overnight. Samples of raw beef liver and raw beef muscle were kept at -80 ${ }^{\circ} \mathrm{C}$ without thawing before use for miRNA procedures (Sauer et al., 2017).

\section{2: DNA Testing for Species Identification}

All samples underwent DNA extraction and quantification, followed by real-time PCR. In instances where real-time PCR failed to detect a species, DNA mini-barcoding was used.

\subsection{1: DNA Extraction and Quantification}

DNA was extracted according to the Qiagen (Hilden, Germany) DNeasy Blood \& Tissue Kit spin-column protocol for total DNA purification from animal tissues. Extraction was carried out on $10 \pm 5 \mathrm{mg}$ of each composite dietary supplement sample and $25 \pm 5 \mathrm{mg}$ of control liver and muscle samples. The sample weight was reduced for the dietary supplements because the samples were dehydrated. Next, buffer ATL $(180 \mu \mathrm{L})$ and proteinase $\mathrm{K}(20 \mu \mathrm{L})$ were added to the tube. The sample was pulse-vortexed for $15 \mathrm{~s}$ and incubated in an Eppendorf Thermomixer C (Hamburg, Germany) at $56{ }^{\circ} \mathrm{C}$ for $4 \mathrm{~h}$. The mixture was vortexed for a total of $15 \mathrm{~s}$, followed by the addition of $200 \mu \mathrm{L}$ buffer $\mathrm{AL}$ and another vortexing step. Next, $200 \mu \mathrm{L}$ ethanol was added and the mixture was vortexed to ensure adequate mixing. The solution was transferred to a $2 \mathrm{~mL}$ collection tube and centrifuged at $6000 \mathrm{x}$ g for $60 \mathrm{~s}$. The flow-through and collection tube were discarded. The sample was combined with $500 \mu \mathrm{L}$ of buffer AW1 and placed in a new collection tube, then centrifuged at $6000 \mathrm{x}$ g for $1 \mathrm{~min}$. Next, $500 \mu \mathrm{L}$ AW2 was added and centrifuged at $20,000 \mathrm{x}$ g for $3 \mathrm{~min}$. The column was transferred to a new $1.5 \mathrm{~mL}$ micro-centrifuge tube and $200 \mu \mathrm{L}$ buffer AE was pipetted onto the DNeasy membrane. After 1 min, the sample was centrifuged at $6000 \mathrm{x}$ g for $1 \mathrm{~min}$. DNA was quantified using a Biophotometer Plus (Eppendorf). The DNA extracts were diluted in AE buffer as needed to obtain a concentration of $20 \mathrm{ng} / \mu \mathrm{L}$ 
before use in real-time PCR. For each set of DNA extractions, a reagent blank control with no sample added was also prepared.

\subsection{2: Multiplex Real-Time PCR}

Multiplex real-time PCR procedures were completed using the Tetraplex Real-Time PCR AllHorse ${ }^{\mathrm{TM}}$ Assay (Microsynth AG, Balgach, Switzerland). Each reaction contained $7.5 \mu \mathrm{L}$ of the AllHorse Assay, $12.5 \mu \mathrm{L}$ of QuantiTect Multiplex PCR NoROX (Qiagen, Hilden, Germany), and $5 \mu \mathrm{L}$ of DNA (20 ng/ $\mu \mathrm{L})$. The sample was placed in a Qiagen Rotor Gene $\mathrm{Q}$ thermocycler and fluorescence detection was measured for ROX, JOE, Cy5, and FAM. The thermal cycling protocol was as follows: $95^{\circ} \mathrm{C}$ for $15 \mathrm{~min}$, then 35 cycles of $95^{\circ} \mathrm{C}$ for $10 \mathrm{~s}$ and $60{ }^{\circ} \mathrm{C}$ for $60 \mathrm{~s}$. Positive control samples for cattle, horse, pork, and sheep were included in each run. For every PCR run, a non-template negative control with no DNA was included.

\subsection{3: DNA Mini-Barcoding}

Samples that failed species identification with real-time PCR underwent DNA barcoding using the mini-barcode primers described in Wu et al. (2019) for mammals, poultry, and fish (FishCOILBC_ts and REVshort1). Each reaction tube consisted of $12.50 \mu \mathrm{L} 10 \%$ trehalose, 8.0 $\mu \mathrm{L}$ molecular grade water, 0.5 Omnimix bead (TaKaRa Bio, Inc, Otsu, Shiga, Japan), $0.25 \mu \mathrm{L}$ forward primer $(10 \mu \mathrm{M}), 0.25 \mu \mathrm{L}$ reverse primer $(10 \mu \mathrm{M})$, and $2.0 \mu \mathrm{L}$ DNA template $(20 \mathrm{ng} / \mu \mathrm{L})$ (Moore et al., 2012). Thermal cycling was carried out as follows: $94{ }^{\circ} \mathrm{C}$ for $5 \mathrm{~min} ; 40$ cycles of $94{ }^{\circ} \mathrm{C}$ for $30 \mathrm{~s}, 51^{\circ} \mathrm{C}$ for $40 \mathrm{~s}$, and $72{ }^{\circ} \mathrm{C}$ at $30 \mathrm{~s} ; 72{ }^{\circ} \mathrm{C}$ for $10 \mathrm{~min}$; then an indefinite hold at 4 ${ }^{\circ} \mathrm{C}$ (Wu et al., 2019). PCR products were stored at $-20{ }^{\circ} \mathrm{C}$. For every mini-barcoding sample set, a non-template negative control with no DNA was included.

PCR products were confirmed as described in Kane and Hellberg (2015) using a pre-cast 2\% agarose double comb E-gel (Life Technologies, Carlsbad, CA). Each sample well contained 
$16 \mu \mathrm{L}$ sterile water and $4 \mu \mathrm{L}$ of PCR product. The gel was run for 15 min using an E-gel iBase Power System (Life Technologies). Images of each gel were obtained by using a Fotodyne Foto/Analyst 220-V UV transilluminator from Carolina Biological (Burlington, NC) and PCIMAGE software. Samples with a positive PCR result and no indication of contamination based on the negative controls underwent DNA sequencing.

PCR products were purified before DNA sequencing with ExoSAP-IT (Affymetrix, Santa Clara, CA), according to the manufacturer's instructions. Samples were shipped on ice overnight to GenScript (Piscataway, NJ) for bi-directional sequencing with the M13 primers described in Wu et al. (2019). Sequencing was carried out with a BigDye Terminator v3.1 Cycle Sequencing Kit (Life Technologies) and 3730xl Genetic Analyzer (Life Technologies). The raw sequence data were assembled and edited using Geneious R7 (Biomatters, Ltd., Auckland, New Zealand). The resulting DNA sequences were searched against all public records in the Barcode of Life Database (BOLD) to identify the top species matches. If a species match was not obtained with BOLD, the sequence was searched in GenBank using the Basic Local Alignment Search Tool (BLAST).

\section{3: MiRNA Testing for MiR-122 Detection}

\subsection{1: MiRNA Extraction and Quantification}

MiRNAs were extracted as total RNA using the $m i r \mathrm{Vana}^{\mathrm{TM}}$ miRNA isolation kit (Life Technologies), according to the manufacturer's instructions. Samples were weighed into $1.5 \mathrm{~mL}$ microcentrifuge tubes and then stored in a Nunc ${ }^{\circledR}$ Labtop Cooler (Nalge Nunc International, Rochester, NY). The sample weights were the same as those used for DNA extraction. Next, the lysis solution at 10x the sample weight $(100-250 \mu \mathrm{L})$ was added to each sample tube and the tubes were vortexed. MiRNA homogenate additive equal to the amount of sample (10-25 $\mu \mathrm{L})$ 
was added and the tubes were vortexed and chilled in the Lab Top Cooler for $10 \mathrm{~min}$. AcidPhenol:Chloroform equal to the amount of lysate $(100-250 \mu \mathrm{L})$ was added and the tubes were vortexed for 30-60 s before centrifuging at 10,000 x g for $5 \mathrm{~min}$. The upper, aqueous phase containing the RNA was transferred to a new $1.5 \mathrm{~mL}$ tube and the volume was recorded. The steps for the enrichment of small RNAs in the mirVana ${ }^{\mathrm{TM}}$ manual were followed to purify the miRNAs from total RNA in the sample. Ethanol was added at 1/3 volume of the aqueous phase and vortexed. The sample was pipetted onto a filter inside a collection tube and centrifuged for $30 \mathrm{~s}$ at $11,000 \mathrm{rpm}$ (equivalent to $10,000 \mathrm{xg}$ ). Ethanol at $2 / 3$ aqueous phase volume was added to the filtrate, mixed gently, and pipetted onto another filter cartridge, and then the centrifuge conditions were repeated. Next, the filter was washed with the mirVana wash solutions, followed by centrifuging for $10 \mathrm{~s}$ after each wash and centrifuged for one min after the final wash. The filter cartridge was placed in a new collection tube and $100 \mu \mathrm{L}$ of pre-heated elution buffer $(95$ ${ }^{\circ} \mathrm{C}$ ) was pipetted onto the filter before centrifuging for $30 \mathrm{~s}$ at 11,000 rpm.

Each extraction run included a reagent blank that contained no tissue sample to verify that samples weren't contaminated during preparation. Two extractions were performed on a cut of beef muscle to serve as a negative control. The miRNA extracts were quantified with a Biophotometer Plus (Eppendorf) and stored at $-20{ }^{\circ} \mathrm{C}$.

\subsection{2: MiRNA Reverse-Transcription}

The miRNA samples were thawed in a Labtop Cooler until completely melted. Meanwhile, the work area and equipment were cleaned with RNaseZap. The reverse transcription master mix was prepared according to the mixture used in the reverse transcription step of the microRNA TaqMan analysis (Kotlarek et al., 2018). Each reagent mix included the following per reaction: $100 \mathrm{mM}$ dNTPs $(0.15 \mu \mathrm{L})$, MultiScribe Reverse Transcriptase $(1.00 \mu \mathrm{L})$, 
10x Reverse Transcription Buffer $(1.50 \mu \mathrm{L}), 20 \mathrm{U} / \mu \mathrm{L}$ RNase Inhibitor $(0.19 \mu \mathrm{L})$, and nucleasefree water $(4.16 \mu \mathrm{L}) .5 \mathrm{xRT}$ primer $(3 \mu \mathrm{L})$ and diluted sample miRNA $(5 \mu \mathrm{L}$ at $2 \mathrm{ng} / \mu \mathrm{L})$ was added to a $0.2 \mathrm{~mL}$ reaction tube and placed in a thermocycler under the following conditions: 85 ${ }^{\circ} \mathrm{C}$ for $5 \mathrm{~min}$ and $60^{\circ} \mathrm{C}$ for $5 \mathrm{~min}$. After cycling, the sample was kept in the Labtop Cooler. Reagent mix $(7 \mu \mathrm{L})$ was added to each sample, mixed, and incubated in the Labtop Cooler for 5 min. Thermocycling conditions used the following parameters: $30 \mathrm{~min}$ at $16{ }^{\circ} \mathrm{C}, 30 \mathrm{~min}$ at $40^{\circ} \mathrm{C}$, 5 min at $85{ }^{\circ} \mathrm{C}$, followed by holding at $4{ }^{\circ} \mathrm{C}$. Samples were stored at $-20^{\circ} \mathrm{C}$ until further testing.

\subsection{3: MiRNA Real-Time PCR}

Real-time PCR amplification followed the TaqMan ${ }^{\mathrm{TM}}$ Universal Master Mix II protocol (Applied Biosystems, Foster City, CA). Each reaction tube contained $10.0 \mu \mathrm{L} \mathrm{TaqMan}^{\mathrm{TM}}$ universal master mix, no UNG, $7.67 \mu \mathrm{L}$ nuclease-free water, $1.00 \mu \mathrm{L}$ TaqMan ${ }^{\mathrm{TM}}$ MicroRNA Assay primer miR-122-5p (20X), and $1.33 \mu \mathrm{L}$ reverse transcription product. The thermocycler was set to FAM fluorescence detection and run under the following conditions: $95^{\circ} \mathrm{C}$ for $10 \mathrm{~min}$, then 40 cycles of $95^{\circ} \mathrm{C}$ for $15 \mathrm{~s}$ and $60^{\circ} \mathrm{C}$ for $60 \mathrm{~s}$. Reverse transcription and real-time PCR were repeated on the same miRNA extract if a sample tested negative for miR-122 expression.

\section{Results and Discussion}

\section{1: Sample Collection}

The 53 beef/bovine liver dietary supplement products collected for this study represented 50 different brand names and 48 manufacturers. The average price per bottle was USD $\$ 19.83$, with a range of $\$ 4.65$ to $\$ 36.00$. The average price per dosage unit was $\$ 0.18 \pm 0.10$, with a range between $\$ 0.02$ and $\$ 0.67$. Two samples did not declare the total amount of servings or units/bottle. The majority of supplements declared a country of origin for the beef/bovine liver in the product: 26 claimed Argentina, 11 claimed New Zealand, 2 claimed both New Zealand and 
Australia, 1 claimed the United States, 1 claimed the United States and Argentina, and 12 were of undeclared geographical origin (Table 2). Two samples (Nos. 50 and 41) claimed to be "handmade" or "homemade." The majority of samples also claimed specific liver processing methods on their labels or websites, such as desiccated $(n=21)$, freeze-dried/lyophilized $(n=10)$, raw $(n=4)$, predigested $(n=2)$, cold processed $(n=1)$, and undefatted $(n=1)$ (Table 2). The addresses included on the label for the manufacturer, distributor, or brand were primarily associated with the United States ( $\mathrm{n}=49)$, followed by New Zealand $(\mathrm{n}=1)$. Three of the products did not have an address or manufacturing country listed.

In addition to bovine/beef liver, some of the most common ingredients declared in the supplements included gelatin $(n=33)$, silicon dioxide $(n=20)$, magnesium stearate $(n=20)$, cellulose $(n=19)$, rice $(n=10)$, ginseng $(n=5)$, and milk thistle $(n=5)$. Six of the supplements (Nos. $5,6,21,24,31$, and 45 ) claimed to contain additional tissues other than bovine/beef liver, with the most common tissues being heart $(\mathrm{n}=3)$, kidney $(\mathrm{n}=3)$, bone $(\mathrm{n}=2)$, and spleen $(\mathrm{n}=2)$. Specifically, sample No. 21 claimed to contain neonatal bovine spleen, heart, pancreas, kidney, liver, adrenal complex, thymus, and lung, as well as lamb brain, pituitary/hypothalamus complex, and intestine; sample No. 24 claimed to contain beef bone broth concentrate, liver, heart and kidney; sample No. 31 claimed raw bovine testicular tissue, prostate tissue, heart tissue, kidney tissue, and liver tissue; and sample No. 45 claimed bovine bone marrow, spleen, and liver.

\section{2: Species Identification with DNA}

A total of $48 / 53$ samples were confirmed to contain bovine species based on the combined results of real-time PCR and DNA mini-barcoding (Table 2). Positive control samples for pork, sheep, domestic cattle, and horse were all correctly detected with the multiplex real- 
time PCR assay, with average $C_{t}$ values of $29.14,30.91,27.24$, and 25.62 , respectively. The multiplex real-time PCR assay detected domestic cattle in 35 samples. One of these samples (No. 21) tested positive for sheep/lamb in addition to cattle, both of which were declared on the label. An additional sample (No. 11) tested positive for undeclared pork (Sus scrofa) in addition to cattle. The only ingredients listed for this sample were "desiccated beef liver powder" and "vegetable capsule," indicating potential mislabeling.

Among the 18 samples that failed real-time PCR, 13 were identified using DNA minibarcoding (Table 2). DNA mini-barcoding identified eight of the samples specifically as $B$. taurus, and five to the Bos genus, with equivalent top matches to B. taurus, Bos frontalis (gayal), and B. taurus indicus (zebu). The genetic marker used for DNA barcoding and mini-barcoding of animal species (COI) is part of the mitochondrial DNA, which is inherited maternally and cannot distinguish between hybrid and purebred species (Kane \& Hellberg, 2016). Hybridization may explain why some of the samples showed equivalent matches to multiple Bos species. Gayal, also called mithun, is the semi-domesticated species of the endangered guar. Gayal is considered endangered in Bangladesh, and there is evidence that gayal has reproduced with B. taurus (Faruque et al., 2015). Therefore, it is likely that some of the BOLD records for gayal contain identical DNA sequences to those for domestic cattle, resulting in an equivalent genetic match to these species. Zebu is a subspecies of $B$. taurus that acclimated to tropical climates before becoming domesticated (Porto-Neto et al., 2013). In addition to the possibility of historical hybridization events, it may be that the mini-barcode targets a section of the mitochondrial genome that has little or no sequence divergence between these closely related species.

Among the five unidentified samples, two failed to produce a sequence and three had short sequence lengths $(<71 \mathrm{bp})$ that did not have a species match in BOLD or GenBank. 
However, there were no trends explaining why these samples failed. While all these samples claimed to contain Argentinean beef/bovine liver, other samples that declared Argentinean beef/bovine liver were successfully identified. The most commonly declared ingredients in these products were rice $(\mathrm{n}=3)$, ginseng $(\mathrm{n}=3)$, milk thistle $(\mathrm{n}=3)$, gelatin $(\mathrm{n}=3)$, silicon dioxide $(\mathrm{n}=3)$, magnesium stearate $(n=2)$ and cellulose $(n=1)$. Ingredients such as gelatin may interfere with DNA extraction and amplification, leading to a higher percentage of failed sequences (Wallace et al., 2012). However, these ingredients were also declared in products that were identified using real-time multiplex PCR or DNA mini-barcoding. Two of the failed samples claimed to contain desiccated liver, while the other three listed no processing methods. In comparison, there were 19 successfully identified samples that claimed to contain desiccated liver. It is important to note that while the lack of species detection suggests potential mislabeling, it does not confirm mislabeling. It might instead indicate a high level of DNA degradation or a need for further optimization of the testing method for use with dietary supplements (Zahn et al., 2020). Additionally, the presence of DNA from plant or other animal species could have interfered with DNA sequencing.

Interestingly, the majority (92.3\%) of samples identified with DNA mini-barcoding failed to produce a sequence read with the forward primer but were identified based on the single sequence read associated with the reverse primer. Wu et al. (2019) reported that these minibarcode primers were successful at identifying $B$. taurus in samples processed under high temperature/high pressure conditions, but not whether bidirectional sequences were obtained. A study on DNA barcoding of meat and poultry products using the universal mini-barcode primers developed by Meusnier et al. (2008) found low success rates for mini-barcoding compared to full-barcoding, which they attributed to less success with primer binding (Hellberg et al. 2017). 
The primer sequences used in the current study were different from those developed by Meusnier et al. (2008), but the forward primer targeted a similar region of the COI gene. While bidirectional sequencing is not always necessary to accurately identify species in a sample, optimization of the forward mini-barcode primer used in the current study might help to improve the identification of species in these products.

Real-time PCR and DNA barcoding have been used in multiple studies to detect food and dietary supplement fraud (Hellberg et al., 2019; Kane \& Hellberg, 2016; Newmaster et al., 2013). The $2 \%$ species mislabeling rate reported in the current study is lower compared to other market surveys on dietary supplement mislabeling, which have reported mislabeling rates of 19 45\% (Hellberg et al., 2019; Morovic et al., 2016; Newmaster et al., 2013; Wallace et al. 2012). The low species mislabeling rate in the current study could be due to high availability of bovine liver for use in supplements and low incentive for substitution. However, it is important to mention that the multiplex real-time PCR used in the current study only tests for pork, horse, sheep, and domestic cattle, and not the presence of any other species (Köppel et al., 2011). If a supplement contained additional species, they would not have been detected with this assay.

\section{3: Organ Verification with MiRNA Detection}

MiRNA real-time PCR detected miR-122 in 51 of the 53 supplements (Table 2). Fifteen samples had $\mathrm{Ct}$ values $\leq 26$ and the remaining 38 samples had $\mathrm{C}_{\mathrm{t}}$ values between 30 and 39 . Interestingly, all samples claiming to contain Argentinean beef had $\mathrm{Ct}$ values $\geq 30$. Beef could have been processed in Argentina before being shipped to the manufacturer, causing sample degradation and higher Ct values. Two supplements (sample Nos. 7 and 33) repeatedly tested negative for miR-122. Sample 7 was positive for beef with the multiplex real-time PCR species assay and sample 33 failed multiplex real-time PCR but was positive for Bos spp. with DNA 
mini-barcoding. These results indicate that the samples contained bovine species but possibly not liver from these species. Both samples that failed miR-122 detection claimed to contain Argentinean beef liver and contained cellulose and magnesium stearate. However, other samples with these ingredients were able to be detected with this assay. Sample 33 claimed to contain predigested liver fractions, which may be more hydrolyzed and could explain why miR-122 was not detected. While previous research has shown that miR-122 is stable and detectable despite degradation, there are some discrepancies (Bail et al., 2010; Courts \& Madea, 2010; Jin et al., 2009; Mraz et al., 2009). For example, miR-122 levels fluctuate depending on disease presence and growth development stage (Casas et al., 2016; Wang et al., 2013; Clarke et al., 2017; Guan et al., 2017; Iguchi et al., 2018).

Interestingly, all five samples that could not be identified with DNA testing contained miR-122. These results suggest that liver was likely present in the supplements, but the species could not be confirmed. The non-template controls and reagent blanks for all trials were negative. However, one of the two negative control beef muscle extracts was positive for miR122 with a Ct value of 38.24 . The PCR assay was repeated for both beef muscle extracts and they were both negative for miR-122, indicating a possible contamination event or weakly positive signal in the first run.

It is important to note that miR-122 is a circulating miRNA and detection of this miRNA does not guarantee that liver is undeniably present. Previous researchers have found low copies of miR-122 in other tissues, such as spleen and adipose tissue, while other studies found no copies of miR-122 in these tissues (Lagos-Quintana et al. 2002; Liang et al. 2007; Liao et al. 2018; Gu et al. 2007; Zhao et al. 2009; Heneghan et al. 2011; Li et al. 2018). MiRNA panels may be more reliable at verifying liver presence since miR-122 is not exclusively expressed in the 
liver. For example, muscle-specific miRNAs for beef are miR-1, miR-133a, and miR-206 (Jin et al., 2009). MiR-9 and miR-124, although found in small amounts in other bovine tissues, can be used to identify brain tissue (Jin et al., 2009). Other miRNAs reported as highly expressed include miR-451 (spleen) and miR-30a (kidney) (Jin et al., 2009). Species-specific miRNAs are being discovered. Examples include miRNAs miR-411, -423-5p, -574-3p, and -652 in beef (Jin et al., 2009). Since miRNAs are often conserved among species in addition to being tissuespecific, it is possible that miRNAs can be used as universal tissue biomarkers (Jin et al., 2009). More research should be conducted to find suitable miRNAs conserved across species for use as universal tissue biomarkers.

MiRNAs also have potential use as indicators to determine if companies are using healthy animals within the expected age. Since miRNA expression differs among sick and healthy animals, detection of miRNA levels in animals can help determine the health status of the animal before slaughter (Forero-Forero, Gonzalez-Teshima, Capal-Herrera, Ramirez-Cheyne, $\&$ Castillo-Giraldo, 2016). If veal (bovine $<18$ weeks old) is claimed on the label, miRNAs can also be used to determine the age of the animal (Forero-Forero et al., 2016; USDA, 2011). 
Table 2: Results of miRNA and DNA identifications for bovine liver supplements tested in this study. Samples were only subjected to DNA mini-barcoding if the real-time PCR assay failed to identify a species

\begin{tabular}{|c|c|c|c|c|c|c|c|}
\hline $\begin{array}{l}\text { Sample } \\
\text { No. }\end{array}$ & Form & $\begin{array}{l}\text { Labeled } \\
\text { species }\end{array}$ & $\begin{array}{l}\text { Beef/bovine } \\
\text { origin }\end{array}$ & Processing claim(s) & $\begin{array}{l}\text { MicroRN } \\
\text { A-122 Ct } \\
\text { value }\end{array}$ & $\begin{array}{l}\text { Real-Time } \\
\text { PCR Species } \\
\text { ID }\left(C_{t}\right)\end{array}$ & $\begin{array}{l}\text { DNA mini- } \\
\text { barcoding ID } \\
(\% \text { similarity })^{\mathrm{a}}\end{array}$ \\
\hline 1 & Capsule & Beef & Argentina & Desiccated & 32.75 & Beef (29.53) & $\mathrm{N} / \mathrm{A}$ \\
\hline 2 & Capsule & Beef & Argentina & Desiccated & 35.48 & Beef (27.19) & $\mathrm{N} / \mathrm{A}$ \\
\hline 3 & Capsule & Beef & $\begin{array}{l}\text { New } \\
\text { Zealand }\end{array}$ & Cold Processed & 19.27 & Beef (21.63) & $\mathrm{N} / \mathrm{A}$ \\
\hline 4 & Softgel & Bovine & Undeclared & Predigested & 36.74 & Beef (32.66) & N/A \\
\hline 5 & Capsule & Beef & $\begin{array}{l}\text { United } \\
\text { States }\end{array}$ & Freeze Dried & 20.58 & Beef (21.39) & $\mathrm{N} / \mathrm{A}$ \\
\hline 6 & Tablet & Beef/Bovine & Argentina & Raw & 31.12 & ND & $\begin{array}{l}\text { B. taurus } / B \text {. } \\
\text { frontalis } / B \text {. } \\
\text { taurus indicus } \\
(100 \%)\end{array}$ \\
\hline 7 & Tablet & Beef/Bovine & Argentina & Desiccated & $\mathrm{ND}^{\mathrm{b}}$ & Beef (28.13) & $\mathrm{N} / \mathrm{A}$ \\
\hline 8 & Capsule & Bovine & $\begin{array}{l}\text { Australia } \\
\text { and New } \\
\text { Zealand }\end{array}$ & Undeclared & 19.21 & Beef (20.79) & $\mathrm{N} / \mathrm{A}$ \\
\hline 9 & Tablet & Bovine & $\begin{array}{l}\text { BSE-Free } \\
\text { Countries }\end{array}$ & Undeclared & 30.2 & Beef (23.95) & $\mathrm{N} / \mathrm{A}$ \\
\hline 10 & Tablet & Beef & Argentina & Desiccated & 36.34 & Beef (32.66) & $\mathrm{N} / \mathrm{A}$ \\
\hline 11 & Capsule & Beef & Argentina & Undeclared & 31.42 & $\begin{array}{l}\text { Pork (37.11), } \\
\text { Beef (28.35) }\end{array}$ & $\mathrm{N} / \mathrm{A}$ \\
\hline 12 & Capsule & Beef & Argentina & Desiccated & 31.65 & Beef (38.14) & $\mathrm{N} / \mathrm{A}$ \\
\hline 13 & Tablet & Beef & Argentina & Desiccated & 34.27 & ND & $\begin{array}{l}\text { B. taurus } \\
(95.65 \%)\end{array}$ \\
\hline 14 & Capsule & Beef/Bovine & Argentina & Undeclared & 35.27 & ND & $\begin{array}{l}\text { B. taurus } / B \text {. } \\
\text { frontalis } / B \text {. } \\
\text { taurus indicus } \\
(100 \%)\end{array}$ \\
\hline 15 & Capsule & Beef & Argentina & Desiccated & 32.64 & Beef (34.69) & $\mathrm{N} / \mathrm{A}$ \\
\hline
\end{tabular}




\begin{tabular}{|c|c|c|c|c|c|c|c|}
\hline 16 & Capsule & Beef & Argentina & Desiccated & 34.21 & Beef (37.83) & N/A \\
\hline 17 & Capsule & Beef/Bovine & $\begin{array}{l}\text { New } \\
\text { Zealand }\end{array}$ & Freeze Dried & 20.41 & $\operatorname{Beef}(27.03)$ & N/A \\
\hline 18 & Capsule & Beef & Argentina & Desiccated & 38.44 & ND & $\begin{array}{l}\text { No species } \\
\text { match }\end{array}$ \\
\hline 19 & Capsule & Bovine & $\begin{array}{l}\text { Australia } \\
\text { and New } \\
\text { Zealand }\end{array}$ & Undeclared & 20.14 & Beef (27.08) & N/A \\
\hline 20 & Capsule & Beef & $\begin{array}{l}\text { New } \\
\text { Zealand }\end{array}$ & $\begin{array}{l}\text { Desiccated/Freeze } \\
\text { Dried }\end{array}$ & 32.81 & $\operatorname{Beef}(30.93)$ & N/A \\
\hline 21 & Tablet & $\begin{array}{l}\text { Bovine, } \\
\text { Ovine }\end{array}$ & Undeclared & Undeclared & 33.07 & $\begin{array}{l}\text { Beef (26.27), } \\
\text { Sheep } \\
(33.00)\end{array}$ & N/A \\
\hline 22 & Capsule & Beef & $\begin{array}{l}\text { New } \\
\text { Zealand }\end{array}$ & Raw & 22.18 & $\operatorname{Beef}(29.18)$ & N/A \\
\hline 23 & Capsule & Bovine & $\begin{array}{l}\text { New } \\
\text { Zealand }\end{array}$ & Freeze Dried & 26.03 & Beef (24.17) & N/A \\
\hline 24 & Capsule & Beef/Bovine & Argentina & $\begin{array}{l}\text { Undefatted, } \\
\text { Desiccated, Freeze } \\
\text { Dried }\end{array}$ & 35.81 & $\operatorname{Beef}(31.57)$ & N/A \\
\hline 25 & Capsule & Beef & Argentina & Undeclared & 34.34 & ND & $\begin{array}{l}\text { No species } \\
\text { match }\end{array}$ \\
\hline 26 & Capsule & Beef & $\begin{array}{l}\text { New } \\
\text { Zealand }\end{array}$ & Desiccated & 32.66 & Beef (31.96) & N/A \\
\hline 27 & Capsule & Beef/Bovine & Undeclared & Freeze Dried & 31.1 & ND & $\begin{array}{l}\text { B. taurus } \\
(99.25 \%)\end{array}$ \\
\hline 28 & Capsule & Bovine & Undeclared & $\begin{array}{l}\text { Desiccated/Freeze } \\
\text { Dried }\end{array}$ & 21.55 & $\operatorname{Beef}(25.90)$ & $\mathrm{N} / \mathrm{A}$ \\
\hline 29 & Capsule & Beef & Argentina & Undeclared & 36.7 & Beef (23.67) & N/A \\
\hline 30 & Capsule & Beef & Argentina & Desiccated & 37.56 & Beef (36.62) & N/A \\
\hline 31 & Capsule & Bovine & $\begin{array}{l}\text { US and } \\
\text { Argentina }\end{array}$ & Raw & 33.5 & Beef (32.50) & N/A \\
\hline 32 & Tablet & Bovine & Undeclared & Undeclared & 21.25 & Beef (28.71) & N/A \\
\hline
\end{tabular}




\begin{tabular}{|c|c|c|c|c|c|c|c|}
\hline 33 & Capsule & Beef & Argentina & Predigested & ND & ND & $\begin{array}{l}\text { Bos spp. } \\
(100 \%)\end{array}$ \\
\hline 34 & Capsule & Beef/Bovine & Argentina & Desiccated & 35.09 & ND & $\begin{array}{l}\text { No species } \\
\text { match }\end{array}$ \\
\hline 35 & Capsule & Bovine & $\begin{array}{l}\text { New } \\
\text { Zealand }\end{array}$ & Desiccated & 20.81 & Beef (26.50) & N/A \\
\hline 36 & Capsule & Bovine & $\begin{array}{l}\text { New } \\
\text { Zealand }\end{array}$ & Freeze Dried & 24.58 & Beef (27.32) & $\mathrm{N} / \mathrm{A}$ \\
\hline 37 & Capsule & Beef & Argentina & Undeclared & 35.82 & ND & $\begin{array}{l}\text { B. taurus } \\
(100 \%)\end{array}$ \\
\hline 38 & Capsule & Beef & Argentina & Undeclared & 36.09 & ND & $\begin{array}{l}\text { Failed } \\
\text { sequencing }\end{array}$ \\
\hline 39 & Capsule & Beef & $\begin{array}{l}\text { New } \\
\text { Zealand }\end{array}$ & Undeclared & 26.04 & Beef (28.70) & N/A \\
\hline 40 & Capsule & Beef & Argentina & Undeclared & 32.14 & ND & $\begin{array}{l}\text { B. taurus } \\
(94.51 \%)\end{array}$ \\
\hline 41 & Capsule & Beef & Undeclared & Handmade & 37.34 & ND & $\begin{array}{l}\text { B. taurus } / B \text {. } \\
\text { frontalis/B. } \\
\text { taurus indicus } \\
(100 \%)\end{array}$ \\
\hline 42 & Powder & Beef & Argentina & Desiccated & 35.71 & Beef (30.53) & $\mathrm{N} / \mathrm{A}$ \\
\hline 43 & Capsule & Beef/Bovine & Argentina & Desiccated & 32.13 & Beef (30.00) & N/A \\
\hline 44 & Capsule & Bovine & Undeclared & Raw/Lyophilized & 36.98 & ND & $\begin{array}{l}\text { B. taurus } \\
(100 \%)\end{array}$ \\
\hline 45 & Capsule & Bovine & Undeclared & Undeclared & 22.72 & $\begin{array}{l}\text { Bovine } \\
(27.35)\end{array}$ & $\mathrm{N} / \mathrm{A}$ \\
\hline 46 & Capsule & Beef & Undeclared & Undeclared & 31.71 & ND & $\begin{array}{l}\text { B. taurus } / B \text {. } \\
\text { frontalis/B. } \\
\text { taurus indicus } \\
(97.73 \%)\end{array}$ \\
\hline 47 & Capsule & Bovine & $\begin{array}{l}\text { New } \\
\text { Zealand }\end{array}$ & $\begin{array}{l}\text { Desiccated/Freeze } \\
\text { Dried }\end{array}$ & 19.72 & Beef (26.80) & $\mathrm{N} / \mathrm{A}$ \\
\hline 48 & Powder & Beef & Undeclared & Desiccated & 33.08 & Beef (32.12) & N/A \\
\hline
\end{tabular}




\begin{tabular}{|c|c|c|c|c|c|c|c|}
\hline 49 & Powder & Beef & Undeclared & Undeclared & 34.99 & ND & $\begin{array}{l}\text { B. taurus } \\
(100 \%)\end{array}$ \\
\hline 50 & Powder & Beef & Argentina & Homemade & 32.53 & ND & $\begin{array}{l}\text { B. taurus } \\
(100 \%)\end{array}$ \\
\hline 51 & Capsule & Beef & $\begin{array}{l}\text { New } \\
\text { Zealand }\end{array}$ & Undeclared & 34.01 & ND & $\begin{array}{l}\text { B. taurus } \\
(100 \%)\end{array}$ \\
\hline 52 & Powder & Beef & Argentina & Undeclared & 33.14 & ND & $\begin{array}{l}\text { Failed } \\
\text { sequencing }\end{array}$ \\
\hline 53 & Capsule & Beef & Argentina & Desiccated & 32.23 & Beef (30.51) & N/A \\
\hline
\end{tabular}

${ }^{a}$ Results are shown as the top species match and \% genetic similarity to reference sequences in BOLD/GenBank

${ }^{\mathrm{b}} \mathrm{ND}=$ Not detected

${ }^{\mathrm{c}}$ GenBank was used because species could not be identified with BOLD 


\section{Conclusions}

This was the first study to use microRNAs for verification of animal tissues in dietary supplements, as well as the first study to focus on the identification of specific animal tissues in dietary supplements. The combined use of real-time multiplex PCR and DNA mini-barcoding was successful at detecting genus or species for the majority (90.6\%) of samples. Individually, real-time multiplex PCR identified $66.0 \%$ of samples and DNA mini-barcoding identified an additional $24.5 \%$ of the samples. Real-time multiplex PCR was beneficial for targeted screening for the presence of beef and other domesticated species. At the same time, DNA mini-barcoding was able to resolve some of the samples not identified using real-time PCR. The results of this study indicate the benefits of using both methods when detecting species in a highly processed sample. However, the inability to identify species in close to $10 \%$ of the samples tested indicates the need for further optimization of these methods for use with dietary supplements. MiR-122 detection was successful for $96.2 \%$ of samples, indicating the presence of liver in most products. However, since miR-122 is a circulating miRNA, it can be detected even when liver is absent. Future research using a panel of miRNAs is recommended for additional confirmation of tissue type. Further development and validation of this method will ultimately enable rapid confirmation of both the species and tissue type declared in dietary supplements and other highly processed products. 


\section{References}

Abdullah, B. M. (2008). Composition, chemical and microbiological properties of Jordanian ovine organ meats. International Journal of Food Science and Technology, 43, 746 - 751. doi:10.1111/j.1365-2621.2007.01516.x

Alvarado, V. M. (2019). By-product report. Retrieved from: https://www.ams.usda.gov/mnreports/nw_ls440.txt

Alvarez-Saavedra, E., \& Horvitz, H. R. (2010). Many families of Caenorhabditis elegans microRNAs are not essential for development or viability. Curr Biol., 20(4), 367 - 373. doi:10.1016/j.cub.2009.12.051

Andreote, A. P. D., Rosario, M. F., Ledur, M. C., Jorge, E. C., Sonstegard, T. S., Matukamalli, L., \& Coutinho, L. L. (2014). Identification and characterization of microRNAs expressed in chicken skeletal muscle. Genetics and Molecular Research, 13(1), 1465 1479. doi:10.4238/2014.March.6.5

Bae, I.-S., Seo, K.-S., \& Kim, S. H. (2018). Identification of endogenous microRNA references in porcine serum for quantitative real-time PCR normalization. Molecular Biology Reports, 45, 943 - 949. doi:10.1007/s11033-018-4242-4

Bail, S., Swerdel, M., Liu, H., Jiao, X., Goff, L. A., Hart, R. P., \& Kiledjian, M. (2010). Differential regulation of microRNA stability. $R N A, 16,1032$ - 1039.

Ballin, N. Z. (2010). Authentication of meat and meat products. Meat Science, 86, 577 - 587. doi:10.1016/j.meatsci.2010.06.001

Belay, E. D. (1999). Transmissible spongiform encephalopathies in humans. Annu. Rev. Microbiol., 53, $283-314$. 
Belay, E. D., \& Schonberger, L. B. (2005). The public health impact of prion diseases. Annu. Rev. Public Health, 26, 191 - 212. doi:10.1146/annurev.publhealth.26.021304.144536

Benatrehina, P. A., Pan, L., Naman, C. B., Li, J., \& Kinghorn, A. D. (2018). Usage, biological activity, and safety of selected botanical dietary supplements consumed in the United States. J Tradit Complement Med, 8(2), 267 - 277. doi:10.1016/j.jtcme.2018.01.006

Boelaert, F., Hugas, M., Pelaez, A. O., Rizzi, V., Stella, P., \& Van Der Stede, Y. (2016). The European Union summary report on data of the surveillance of ruminants for the presence of transmissible spongiform encephalopathies (TSEs) in 2015. EFSA Journal, 14(12). doi:10.2903/j.efsa.2016.4643

Brown, A. C. (2017). An overview of herb and dietary supplement efficacy, safety and government regulations in the United States with suggested improvements. Part 1 of 5 series. Food and Chemical Toxicology, 107, 449 - 471. doi:10.1016/j.fct.2016.11.001

California Attorney General (2015). Proposition 6: Criminal law. Prohibition on slaughter of horses and sale of horsemeat for human consumption. Initiative statute.

Casas, E., Cai, G., Kuehn, L. A., Register, K. B., McDaneld, T. G., \& Neill, J. D. (2016). Association of microRNAs with antibody response to Mycoplasma bovis in beef cattle. PLoS ONE, 11(8). doi:10.1371/journal.pone.0161651

Chang, J., Nicolas, E., Marks, D., Sander, C., Lerro, A., Buendia, M. A., Xu, C., Mason, W. S., Moloshok, T., Bort, R., Zaret, K. S., \& Taylor, J. M. (2004). MiR-122, a mammalian liver-specific microRNA, is processed from hor mRNA and may downregulate the high affinity cationic amino acid transporter CAT-1. RNA Biology, 1(2), 106 - 113. 
Chen, W., Fang, G.-F., Wang, S.-D., Wang, H., \& Zeng, Y.-Q. (2017). Characterization and differential expression of microRNA in skeletal muscle of Laiwu and Yorkshire pig breeds. Genes Genom, 39, 173 - 182. doi:10.1007/s13258-016-0484-5

Chen, Y.-W., Song, S., Weng, R., Verma, P., Kugler, J.-M., Buescher, M., . . Cohen, S. M. (2014). Systematic study of Drosophila microRNA functions using a collection of targeted knockout mutations. Developmental Cell, 31, 784 - 800): Developmental Cell.

Chiang, K., Shu, J., Zempleni, J., \& Cui, J. (2015). Dietary microRNA database (DMD): An archive database and analytical tool for food-borne microRNAs. PLoS ONE, 10(6). doi:10.1371/journal.pone.0128089

Clarke, J. I., Forootan, S. S., Lea, J. D., Howell, L. S., Rodriguez, J. M., Kipar, A., Goldring, C. E., Park, B. K., Copple, I. M., \& Antoine, D. J. (2017). Circulating levels of miR-122 increase post-mortem, particularly following lethal dosing with pentobarbital sodium: implications for pre-clinical liver injury studies. Toxicology Research, 6(4), 406 - 411.

Courts, C., \& Madea, B. (2010). Micro-RNA - A potential for forensic science? Forensic Science International, 203, 106 - 111. doi:10.1016/j.forsciint.2010.07.002

Dalsecco, L. S., Palhares, R. M., Oliveira, P. C., Teixeira, L. V., Drummond, M. G., \& Andrade de Oliveira, D. A. A. (2018). A fast and reliable real-time PCR method for detection of ten animal species in meat products. Journal of Food Science, 83(2), 258 - 265.

Danezis, G. P., Tsagkaris, A. S., Camin, F., Brusic, V., \& Georgiou, C. A. (2016). Food authentication: techniques, trends \& emerging approaches. Trends in Analytical Chemistry, 85, 123 - 132. 
Ershoff, Benjamin H. (1951). Beneficial effect of liver feeding on swimming capacity of rats in cold water. Proceedings of the Society for Experimental Biology and Medicine, 77(3), $488-491$.

Ershoff, B. H. (1952). Increased survival of liver-fed rats administered multiple sublethal doses of x-irradiation. The Journal of Nutrition, 47(2), 289 - 298.

Fang, C., Zhao, J., Li, J., Qian, J., Liu, X., Sun, Q., Liu, W., Tian, Y., Ji, A., Wu, H., \& Yan, J. (2019). Massively parallel sequencing of microRNA in bloodstains and evaluation of environmental influences on microRNA candidates using realtime polymerase chain reaction. Forensic Science International: Genetics, 38, 32 - 38.

Faruque, M. O., Rahaman, M. F., Hoque, M. A., Ikeya, K., Amano, T., Han, J. L., Dorgi, T., \& Omar, A. I. (2015). Present status of gayal (Bos frontalis) in the home tract of Bangladesh. Bang. J. Anim. Sci., 44(1), 75 - 84.

Fayemi, P. O., Muchenge, V., Yetim, H., \& Ahhmed, A. (2018). Targeting the pains of food insecurity and malnutrition among internally displaced persons with nutrient synergy and analgesics in organ meat. Food Research International, 10448 - 58.

Fayemi, P. O., Muchenje, V., Yetim, H., \& Ahhmed, A. (2018). Targeting the pains of food insecurity and malnutrition among internally displaced persons with nutrient synergy and analgesics in organ meat. Food Research International, 104, 48 - 58.

FDA. (1938). Title 21: Food and Drugs $\S 343$. Electronic code of federal regulations.

FDA. (2014). Hageman Dairy Farms 12/23/14. (CMS 444637). Online Retrieved from https://wayback.archiveit.org/7993/20170722063104/https://www.fda.gov/ICECI/EnforcementActions/Warning Letters/2014/ucm428057.htm 
FDA. (2017). Food facts: dietary supplements. Retrieved from https://www.fda.gov/downloads/Food/DietarySupplements/UCM240978.pdf

FDA. (2018a). Authorized Health Claims That Meet the Significant Scientific Agreement (SSA)

Standard. Food Labeling \& Nutrition. Retrieved from https://www.fda.gov/food/foodlabeling-nutrition/authorized-health-claims-meet-significant-scientific-agreement-ssastandard

FDA. (2018b). Dietary Supplement Labeling Guide. Retrieved from https://www.fda.gov/Food/GuidanceRegulation/GuidanceDocumentsRegulatoryInformati on/DietarySupplements/ucm2006823.htm

FDA. (2018c). Import Alert 54-17. Retrieved from https://www.accessdata.fda.gov/cms_ia/importalert_1151.html

Fields, A. T., Abercrombie, D. L., Eng, R., Feldheim, K., Chapman, D. D. (2015). A Novel Mini-DNA Barcoding Assay to Identify Processed Fins from Internationally Protected Shark Species. PLoS ONE, 10(2). https://doi.org/10.1371/journal.pone.0114844

Folmer, O., Black, M., Hoeh, W., Lutz, R., \& Vrijenhoek, R. (1994). DNA primers for amplification of mitochondrial cytochrome c oxidase subunit I from diverse metazoan invertebrates. Molecular Marine Biology and Biotechnology, 3(5), 294 - 299.

Food; Exemptions from Labeling. 21 C.F.R. $§ 101.100$ (2020). Retrieved from https://www.ecfr.gov/cgi-bin/textidx?SID=60b45b84698821a866ae0509be991606\&mc=true\&node=se21.2.101_1100\&rg $\mathrm{n}=\operatorname{div} 8$

Food Safety Authority of Ireland. (2013). FSAI survey finds horse DNA in some beef burger products [Press release]. Retrieved from 
https://web.archive.org/web/20130120134255/http:/www.fsai.ie/news_centre/press_relea ses/horseDNA15012013.html

Forero-Forero, J. V., González-Teshima, L. Y., Capal-Herrera, A. M., Ramírez-Cheyne, J., \& Castillo-Giraldo, A. (2016). Emergence of micro-RNA as potential biomarkers in various diseases. Latreia, 29(3), $323-333$.

Gangidi, R. R., \& Proctor, A. (2009). Meat and meat products. In D.-W. Sun (Ed.), Infrared Spectroscopy for Food Quality Analysis and Control: Elsevier, Inc.

Gatfield, D., Martelot, G. L., Vejnar, C. E., Gerlach, D., Schaad, O., Fleury-Olela, F., Ruskeepää, Anna-Liisa, Oresic, Matej, Esau, Christine C., Zdobnov, Evgeny M., \& Schibler, U. (2009). Integration of microRNA miR-122 in hepatic circadian gene expression. Genes \& Development, 23, 1313 - 1326.

Gochfeld, M., \& Burger, J. (1987). Heavy metal concentrations in the liver of three duck species: influence of species and sex. Environmental Pollution, 45(1), 1 - 15. doi:10.1016/02697491(87)90012-1

Griffiths-Jones, S., Grocock, R. J., van Dongen, S., Bateman, A., \& Enright, A. J. (2006). miRBase: microRNA sequences, targets, and gene nomenclature. Nucleic Acids Research, 34(Database). doi:10.1093/nar/gkj112

Gu, Z., Eleswarapu, S., \& Jiang, H. (2007). Identification and characterization of microRNAs from the bovine adipose tissue and mammary gland. FEBS Letters, 581(5), 981-988. doi:10.1016/j.febslet.2007.01.081

Guan, J., Long, K., Ma, J., Zhang, J., He, D., Jin, L., Tang, Q., Jiang, A., Wang, X., Hu, Y., Tian, S., Jiang, J., Li, M., \& Luo, X. (2017). Comparative analysis of the microRNA 
transcriptome between yak and cattle provides insight into high-altitude adaptation. PeerJ, 5. doi:10.7717/peerj.3959

Gustafson, D., Tyryshkin, K., \& Renwick, N. (2016). MicroRNA-guided diagnostics in clinical samples. Best Practice \& Research Clinical Endocrinology \& Metabolism, 30(5), 563 575.

Hanif, Q., Farooq, M., Amin, I., Mansoor, S., Zhang, Y., \& Khan, Q. M. (2018). In silico identification of conserved miRNAs and their selective target gene prediction in indicine (Bos indicus) cattle. PLoS ONE, 13(10). doi:10.1371/journal.pone.0206154

Hashemi, M. (2018). Heavy metal concentrations in bovine tissues (muscle, liver and kidney) and their relationship with heavy metal contents in consumed feed. Ecotoxicology and Environmental Safety, 154, 263 - 267. doi:10.1016/j.ecoenv.2018.02.058

Hellberg, R., Isaacs, R., \& Hernandez, E. (2019). Identification of shark species in commercial products using DNA barcoding. Fisheries Research, 210, 81 - 88. doi:10.1016/j.fishres.2018.10.010

Hellberg, R. S., Hernandez, B. C., \& Hernandez, E. L. (2017). Identification of meat and poultry species in food products using DNA barcoding. Food Control, 80, 23 - 28. doi:10.1016/j.foodcont.2017.04.025

Hellberg, R. S., Isaacs, R. B., \& Hernandez, E. L. (2019). Identification of shark species in commercial products using DNA barcoding. Fisheries Research, 210, 81 - 88. doi:10.1016/j.fishres.2018.10.010

Hellberg, R. S. R., \& Morrissey, M. T. (2011). Advances in DNA-based techniques for the detection of seafood species substitution on the commercial market. J Lab Autom, 16(4), 308 - 321. doi:10.1016/j.jala.2010.07.004 
Hemmer, W., Klug, C., \& Swoboda, I. (2016). Update on the bird-egg syndrome and genuine poultry meat allergy. Allergo J Int, 25, 68 - 75. doi:10.1007/s40 629-016-0102-8

Heneghan, H. M., Miller, N., McAnena, O. J., O'Brien, T., \& Kerin, M. J. (2011). Differential miRNA expression in omental adipose tissue and in the circulation of obese patients identifies novel metabolic biomarkers. J Clin Endocrinol Metab., 96(5), E846-E850. doi:10.1210jc.2010-2701

Herbert, P. D. N., Cywinska, A., Ball, S. L., \& deWaard, J. R. (2003). Biological identifications through DNA barcodes. Proc. R. Soc. Long., B(270), 313 - 321. doi:10.1098/rspb.2002.2218

Hicks, J. A., Tembhurne, P. A., \& Liu, H.-C. (2009). Identification of microRNA in the developing chick immune organs. Immunogenetics, 61, 231 - 240. doi:10.1007/s00251009-0355-1

Hollis, A. R., \& Starkey, M. P. (2018). MicroRNAs in equine veterinary science. Equine Veterinary Journal, 50, 721 - 726. doi:10.1111/evj.12954

Hsieh, Y. P., Woodward, B. B., \& Ho, S. H. (1995). Detection of species substitution in raw and cooked meats using immunoassays. Journal of Food Protection, 58(5), 555 - 559.

Hsu, M. T., \& Coca-Prados, M. (1979). Electron microscopic evidence for the circular form of RNA in the cytoplasm of eukaryotic cells. Nature, 280, 340. doi:10.1038/280339a0 Huyben, D., Boqvist, S., Passoth, V., Renström, L., Bengtsson, U. A., Andréoletti, O., Kiessling, A., Lundh, T., \& Vågsholm, I. (2018). Screening of intact yeasts and cell extracts to reduce Scrapie prions during biotransformation of food waste. Acta Veterinaria Scandinavica, 60(9). doi:10.1186/s13028-018-0363-y 
Iguchi, T., Niino, N., Tamai, S., Sakurai, K., \& Mori, K. (2018). Absolute quantification of plasma microRNA levels in Cynomolgus monkeys, using quantitative real-time reverse transcription PCR. J. Vis. Exp., 132. doi:10.3791/56850

Ioannidis, J., \& Donadeu, F. X. (2016). Circulating miRNA signatures of early pregnancy in cattle. BMC Genomics, 17(184). doi:10.1186/s12864-016-2529-1

Ivanova, N. V., Clare, E. L., \& Borisenko, A. V. (2012). DNA barcoding in mammals. In W. J. Kress \& D. L. Erickson (Eds.), (Vol. 858). DNA barcodes: methods and protocols.

Jin, W., Grant, J. R., Stothard, P., Moore, S. S., \& Guan, L. L. (2009). Characterization of bovine miRNAs by sequencing and bioinformatics analysis. BMC Molecular Biology, 10(90).

Johnson, R. (2014). Food fraud and "economically motivated adulteration" of food and food ingredients. CRS Report. Retrieved from: https://fas.org/sgp/crs/misc/R43358.pdf

Jopling, C. L. (2012). Liver-specific microRNA-122. RNA Biology, 9(2).

Kakimoto, Y., Tanaka, M., Kamiguchi, H., Ochiai, E., \& Osawa, M. (2016). MicroRNA stability in FFPE tissue samples: dependence on GC content. PLOS ONE, 11(9). doi:10.1371/journal.pone. 0163125

Kane, D. E., \& Hellberg, R. S. (2016). Identification of species in round meat products sold on the U.S. commercial market using DNA-based methods. Food Control, 59, 158 - 163.

Karnkowska, A., Vacek, V., Zubáčová, Z., Treitli, S. C., Petrželková, R., Eme, L., Novák, L., Žárský, V., Barlow, L. D., Herman, E. K., Soukal, P., Hroudová, M., Doležal, P., Stairs, C. W., Roger, A. J., Eliáš, M., Dacks, J. B., Vlček, Č., \& Hampl, V. (2016). A eukaryote without a mitochondrial organelle. Current Biology, 26, 1274 - 1284. doi:http://dx.doi.org/10.1016/j.cub.2016.03.053 
Köppel, R., Daniels, M., Felderer, N., \& Brünen-Nieweler, C. (2013). Multiplex Real-Time PCR for the Detection and Quantification of DNA from Duck, Goose, Chicken, Turkey, and Pork. Eur Food Res Technol, 236, 1093 - 1098.

Köppel, R., Ruf, J., \& Rentsch, J. (2011). Multiplex real-time PCR for the detection and quantification of DNA from beef, pork, horse, and sheep. Eur Food Res Technol, 232, $151-155$.

Kress, W. J., \& Erickson, D. L. (2008). DNA barcodes: genes, genomics, and bioinformatics. Proc Natl Acad Sci USA, 105(8), 2761 - 2762. doi:10.1073/pnas.0800476105

Kwon, C., Han, Z., Olson, E. N., \& Srivastava, D. (2005). MicroRNA1 influences cardiac differentiation in Drosophila and regulates Notch signaling. PNAS, 102(52). doi:10.1073/pnas.0509535102

Laganà, A., Veneziano, D., Spata, T., Tang, R., Zhu, H., Mohler, P. J., \& Kilic, A. (2015). Identification of general and heart-specific miRNAs in sheep (Ovis aries). PLoS ONE, 10(11).

Lagos-Quintana, M., Rauhut, R., Yalcin, A., Meyer, J., Lendeckel, W., \& Tuschl, T. (2002). Identification of tissue-specific microRNAs from mouse. Current Biology, 12, 735 - 739.

Lee, R. C., Feinbaum, R. L., \& Ambros, V. (1993). The C. elegans heterochronic gene lin-4 encodes small RNAs with antisense complementarity to lin-14. Cell, 75(5), 843 - 854.

Li, N., Zhang, Y., Li, H.-P., Han, L., Yan, X.-M., Li, H.-B., Du, W., Zhang, J.-S., \& Yu, Q.-L. (2018). Differential expression of mRNA-miRNAs related to intramuscular fat content in the longissimus dorsi in Xinjiang brown cattle. PLoS ONE, 13(11). doi:https://doi.org/10.1371/journal.pone.0206757 
Li, X., \& Carthew, R. W. (2005). A microRNA mediates EGF receptor signaling and promotes photoreceptor differentiation in the drosophila eye. Cell, 123, 1267 - 1277. doi:10.1016/j.cell.2005.10.040

Liang, Y., Ridzon, D., Wong, L., \& Chen, C. (2007). Characterization of microRNA expression profiles in normal human tissues. BMC Genomics, 8(166). doi:10.1186/1471-2164-8-166

Liao, C.-H., Wang, C.-Y., Liu, K.-H., Liu, Y.-Y., Wen, M.-S., \& Yeh, T.-S. (2018). MiR-122 marks the differences between subcutaneous and visceral adipose tissues and associates with the outcome of bariatric surgery. Obesity Research \& Clinical Practice, 12(8), 570 577. doi:https://doi.org/10.1016/j.orcp.2018.06.005

Ma, X., Zhang, Y., Qiao, F., Wang, M., Zuo, Z., Zhang, Y., \& Wang, Y. (2018). Comparison of RNA extraction and microRNA detection protocols for a small amount of germinal vesicle oocytes in bovine. Animal Reproduction Science, 195, 112 - 120. doi:10.1016/j.anireprosci.2018.05.013

Mano, J., Nishitsuji, Y., Kikuchi, Y., Fukudome, S.-i., Hayashida, T., Kawakami, H., Kurimoto, Y., Noguchi, A., Kondo, K., Teshima, R., Takabatake, R., \& Kitta, K. (2017). Quantification of DNA fragmentation in processed foods using real-time PCR. Food Chemistry, 226, 149 - 155. doi:10.1016/j.foodchem.2017.01.064

Merriam-Webster. (n.d.). Bovine. Retrieved April 30, 2020 from https://www.merriamwebster.com/dictionary/bovine

Meusnier, I., Singer, G. A. C., Landry, J. -F., Hickey, D. A., Hebert, P. D. N., Hajibabaei, M. (2008). A universal DNA mini-barcode for biodiversity analysis. BMC Genomics, 9. https://doi.org/10.1186/1471-2164-9-214 
Mohamad, N. A., Mustafa, S., Mokhtar, N. F. K., \& El Sheikha, A. F. (2018). Molecular beaconbased real-time PCR method for detection of porcine DNA in gelatin and gelatin capsules. J. Sci. Food Agric., 98, 4570 - 4577. doi:10.1002/jsfa.8985

Moore, M., Handy, S., Haney, C., Pires, G., Perry, L., Deeds, J., \& Yancy, H. (2012). Updates to the FDA single laboratory validated method for DNA barcoding for the species identification of fish. Retrieved from https:/www.fda.gov/food/dna-based-seafoodidentification/single-laboratory-validated-method-dna-barcoding-species-identificationfish

Morovic, W., Hibberd, A. A., Zabel, B., Barrangou, R., \& Stahl, B. (2016). Genotyping by PCR and high-throughput sequencing of commercial probiotic products reveals composition biases. Frontiers in microbiology, 7. doi:10.3389/fmicb.2016.01747

Morrison, E. E. (2018). Development of circulatory microRNAs as markers of organ injury and mediators of inter-organ signalling. (Doctor of Philosophy). University of Edinburgh,

Mraz, M., Malinova, K., Mayer, J., \& Pospisilova, S. (2009). MicroRNA isolation and stability in stored RNA samples. Biochemical and Biophysical Research Communications, 390, 14. doi:10.1016/j.bbrc.2009.09.061

Mullis, K. B., \& Faloona, F. A. (1987). Specific synthesis of DNA in vitro via a polymerasecatalyzed chain reaction. Methods in Enzymology, 155, 335 - 350. doi:10.1016/00766879(87)55023-6

Na, J.-Y., \& Park, J.-T. (2018). Postmortem RNA stability and availability of microRNAs in postmortem body fluids in forensic medicine. Rom. J. Leg. Med., 26, 167 - 172. doi:10.4323/rjlm.2018.167 
Newmaster, S. G., Grguric, M., Shanmughanandhan, D., Ramalingam, S., \& Ragupathy, S.

(2013). DNA barcoding detects contamination and substitution in north American herbal products. BMC Medicine, 11 .

NIH. (2019). Dietary supplement label database. from US National Library of Medicine https://www.dsld.nlm.nih.gov/dsld/index.jsp\#about

Nutrition Labeling of Dietary Supplements. 21 C.F.R. $§ 101.36$ (2020). Retrieved from https://www.accessdata.fda.gov/scripts/cdrh/cfdocs/cfcfr/CFRSearch.cfm?CFRPart=101 \&showFR=1\&subpartNode $=21: 2.0 .1 \cdot 1 \cdot 2.3$

Permenter, M. G., McDyre, B. C., Ippolito, D. L., \& Stallings, J. D. (2019). Alterations in tissue microRNA after heat stress in the conscious rat: potential biomarkers of organ-specific injury. BMC Genomics, 20. doi:10.1186/s12864-019-5515-6

Porto-Neto, L., Sonstegard, T., Liu, G., Bickhart, D., Da Silva, M., Machado, M., Utsunomiya, Y. T., Garcia, J. F., Gondro, C., \& Van Tassell, C. (2013). Genomic divergence of zebu and taurine cattle identified through high-density SNP genotyping. BMC Genomics, 14(1). doi:10.1186/1471-2164-14-876

Renalier, M. H., Tirmarche, S., \& Zeitz, H. (2011). Biological functions of microRNAs in animals. In J. A. Mulligan (Ed.), MicroRNA: Expression, Detection, and Therapeutic Strategies (pp. 190 - 216): Nova Science Publishers, Inc.

Romao, J. M., Jin, W., He, M., McAllister, T., \& Guan, L. L. (2012). Altered microRNA expression in bovine subcutaneous and visceral adipose tissues from cattle under different diet. PLoS ONE, 7(7). doi:10.1371/journal.pone.0040605 
Romao, J. M., Jin, W., He, M., McAllister, T., \& Guan, L. L. (2014). MicroRNAs in bovine adipogenesis: genomic context, expression and function. BMC Genomics, 15(137). doi:10.1186/1471-2164-15-137

Saccone, C., De Giorgi, C., Gissi, C., Pesole, G., \& Reyes, A. (1999). Evolutionary genomics in Metazoa: the mitochondrial DNA as a model system. Gene, 238, 195 - 209.

Saiki, R. K., Gelfand, D. H., Stoffel, S., Scharf, S. J., Higuchi, R., Horn, G. T., Mullis, K. B., \& Erlich, H. A. (1988). Primer-directed enzymatic amplification of DNA with a thermostable DNA polymerase. Science, 239(4839), 487 - 491.

Sauer, E., Extra, A., Cachée, P., \& Courts, C. (2017). Identification of organ tissue types and skin from forensic samples by microRNA expression analysis. Forensics Science International: Genetics, 28, 99 - 110. doi:10.1016/j.fsigen.2017.02.002

Sauer, E., Reinke, A.-K., \& Courts, C. (2016). Differentiation of five body fluids from forensic samples by expression analysis of four microRNAs using quantitative PCR. Forensic Science International: Genetics, 22, 89 - 99. doi:10.1016/j.fsigen.2016.01.018

Schwarze, K., Buchanan, J., Taylor, J. C., \& Wordsworth, S. (2018). Are whole-exome and whole-genome sequencing approaches cost-effective? A systematic review of the literature. Genetics in Medicine, 20(10), 1122 - 1130. doi:10.1038/gim.2017.247

Song, J., Song, J., Mo, B., \& Chen, X. (2015). Uridylation and adenylation of RNAs. Science China Life Sciences, 58(11), 1057-1066. doi:10.1007/s11427-015-4954-9

Sultana, S., Ali, M. E., Hossain, M. A. M., Asing, Naquiah, N., \& Zaidul, I. S. M. (2018). Universal mini COI barcode for the identification of fish species in processed products. Food Research International, 105, 19-28. 
Sun, J., Zhou, Y., Cai, H., Lan, X., Lei, C., Zhao, X., Zhang, C., \& Chen, H. (2014). Discovery of novel and differentially expressed microRNAs between fetal and adult backfat in cattle. PLoS ONE, 9(2). doi:10.1371/journal.pone.0090244

USDA. (2011). Food safety information: veal from farm to table. Retrieved from: https://www.fsis.usda.gov/wps/wcm/connect/c1c3ed6a-c1e5-4ad0-ba6cd53d71d741c6/Veal_from_Farm_to_Table.pdf?MOD=AJPERES

USDA. (2020a). Retail prices for beef, pork, poultry cuts, eggs, and dairy products. Retrieved from: https://www.ers.usda.gov/data-products/meat-price-spreads/

USDA. (2020b). Food safety education: beef from farm to table. Retrieved from: https://www.fsis.usda.gov/wps/portal/fsis/topics/food-safety-education/get-answers/foodsafety-fact-sheets/meat-preparation/beef-from-farm-to-table/ct_index

Wallace, L. J., Boilard, S. M. A. L., Eagle, S. H. C., Spall, J. L., Shokralla, S., \& Hajibabaei, M. (2012). DNA barcodes for everyday life: routine authentication of natural health products. Food Research International, 49, 446 - 452. doi:http://dx.doi.org/10.1016/j.foodres.2012.07.048

Wang, Q., Cai, Y., He, Y., Yang, L., \& Pan, L. (2018). Collaborative ring trial of two real-time PCR assays for the detection of porcine- and chicken-derived material in meat products. PLoS ONE, 13(10). doi:10.1371/journal.pone.0206609

Wang, X., Gu, Z., \& Jiang, H. (2013). MicroRNAs in farm animals. Animal, 7(10), 1567 - 1575. doi:10.1017/S1751731113001183

Wang, Y., Xing, Q.-F., Liu, X.-Q., Guo, Z.-J., Li, C.-Y., \& Sun, G. (2016). MiR-122 targets VEGFC in bladder cancer to inhibit tumor growth and angiogenesis. Am J Transl Res, $8(7), 3056-3066$. 
Wang, Z., Zhang, J., Luo, H., Ye, Y., Yan, J., \& Hou, Y. (2013). Screening and confirmation of microRNA markers for forensic body fluid identification. Forensic Science International: Genetics, 7, 116 - 123. doi:10.1016/j.fsigen.2012.07.006

Weigt, L. A., Driskell, A. C., Ormos, A., Meyer, C., \& Collins, A. (2012). Introduction to animal DNA barcoding protocols. In W. J. Kress \& D. L. Erickson (Eds.), DNA Barcodes: Methods and Protocols: Springer Science and Business Media, LLC.

What specifications must you establish? 21 C.F.R. $\$ 111.70$ (2020). Retrieved from https://www.ecfr.gov/cgi-bin/textidx?SID=1953d38eb065d0093dfdd99907886bb9\&mc=true\&tpl=/ecfrbrowse/Title21/21c fr111_main_02.tpl

Wong, X. L., \& Sebaratnam, D. F. (2018). Mammalian meat allergy. International Journal of Dermatology, 57, 1433 - 1436. doi:10.1111/ijd.14208

Wu, Y., Yang, Y., Liu, M., Wang, B., Wang, Y., \& Wang, H. (2019). Applying COI barcode to identify animal origin of food. Journal of Food Science, 84(6), 1256 - 1265.

Zahn, R., Silva, A., \& Hellberg, R. (2020). Development of a DNA mini-barcoding protocol targeting COI for the identification of elasmobranch species in shark cartilage pills. Food Control, 109. doi:https://doi.org/10.1016/j.foodcont.2019.106918

Zhang, Y., Jia, Y., Zheng, R., Guo, Y., Wang, Y., Guo, H., Fei, M., \& Shuhan, S. (2010). Plasma microRNA-122 as a biomarker for viral-, alcohol-, and chemical-related hepatic diseases. Clinical Chemistry, 56(12), 1830 - 1838.

Zhao, E., Keller, M. P., Rabaglia, M. E., Oler, A. T., Stapleton, D. S., Schueler, K. L., Neto, E. C., Moon, J. Y., Wang, P., Wang, I. -M., Lum, P., Ivanovska, I., Greenawalt, D., Tsang, J., Choi, Y., Kleinhanz, R., Shang, J., Zhou, Y. -P., Howard, A. D., Zhang, B. B., 
Kendziorski, C., Thornberry, N. A., Yandell, B. S., Schadt, E. E., \& Attie, A. D. (2009). Obesity and genetics regulate microRNAs in islets, liver, and adipose of diabetic mice. Mamm Genome, 20(8), 476-485. doi:10.1007/s00335-009-9217-2

Zorc, M., Obsteter, J., Dovc, P., \& Kunej, T. (2015). Genetic variability of miRNA genes in 15 animal species. Journal of Genomics, 3, 51 - 56. doi:10.7150/jgen.11246 